\title{
Food Tourism Revisited
}

\author{
Ramesh Raj Kunwar*
}

"to eat is a necessity, but to eat intelligently is an art' (Francois de La Rochefoucauld-1613-1680; in Buiatti, 2011, p. 100).

\begin{abstract}
Though food is the basic need of human being, it is the best way to express the culture and the tradition of a community. Food as a tangible part of cultural and traditional representation attracts most of tourists around the world. Food is one of the important pulling factors while selecting the destination. Though after information revolutions most of the facilities are at a click distance, food is the only one that needs the distance to be covered in order to discover the majestic taste in the native structure. Food majorly describes the patterns that communities are residing. Most of the native cuisine that attracts most of the foreigners is based on the native resources and way of preparing and presenting foods. In some countries food is not only taken as a means to generate income but also a means to protect their tourism.
\end{abstract}

Keywords: serious leisure, foodscapes, gastronomy, slow food, sustainability, brand management.

\section{The Concept}

According to the definition of Business Dictionary, food is "edible or potable substance (usually of animal or plant origin), consisting of nourishing and nutritive components such as carbohydrates, fats, proteins, essential mineral and vitamins, which (when ingested and assimilated through digestion) sustains life, generates energy, and provides growth, maintenance, and health of the body" (www. businessdictionary.com).

Food is a common language. It is spoken to communicate, to share emotions, feelings and sensations. Food is also closely connected to the ritual and religious life of the people. Food has a high potential to become used in symbolic contexts. Food

\footnotetext{
* Prof. Dr. Ramesh Raj Kunwar is the author of eight books on tourism and anthropology. He is tourism educationist and anthropologist by profession. He is the former Dean of Faculty of Humanities and Social Sciences, Tribhuvan University, Kathmandu, Nepal. He is also the former Dean of (then) Royal Nepalese Military Academy. Currently, he is teaching at the Department of Conflict, Peace and Development Studies (DCPDS) and Nepal Armed Police Force Command and Staff College, Kathmandu. Email: kunwardr@gmail.com
} 
is the manifestation of exchange crossing the boundary (symbolically the mouth) between inner self and the outer world (the other) (Sheringham \& Daruwalla, 2007).

Folklorist, food scholars, and food aficionados have long been fascinated by occasions of exploratory eating - instances of eating the new, the unfamiliar, the alien - and by the institutions and artifacts which enable those occasions, such as "ethnic" restaurants, international cookbooks, and folklife festivals (Long, 1998, p. $181, \mathrm{FN} 1$ ).

In the field of hospitality, the pleasure of food is not only based on the taste but on the sharing of it with others. Sharing food means talking about the pleasures of the table or any eatable places and this, in turn means talking about hospitality. Nobody can really enjoy their food considering that it is a universal right and that each kind of food, even the most common and "simple", presents many histories that could be told, history of region, history of an identity, history of a population, history of a village, history of a family, history of a religion, in a word, history of a culture (Buiatti, 2011: 93).

Historically, people secured food through two methods: hunting and gathering and agriculture. Today, most of the food energy consumed by the world population is supplied by the food industry, which is operated by multinational corporations that use intensive farming and industrial agriculture to maximize system output (www. wikipedia.com).

In 1943, Maslow, as cited by Doshi (1995,p.22) identified the basic human needs as physiological- safety or security, love or belongingness, esteem or status, and selfactualization. The concept of food thus is quite comprehensive. Physiologically, highest priority of all human beings is to survive. People will eat anything that they perceive might provide nourishment. At the personal level, food and people interaction in a society are related to (a) satisfaction of the basic human needs, and (b) people's beliefs concerning proper relations to their food, which may reduce to a definition of which foods are suitable to eat under certain circumstances. Malinowski has argued in his study of Trobrianders that the main function of food in a society is for human survival. He has pointed out that human body's need for food has done much to shape society through all the activities concerned with food production, distribution and utilization (1944;in Doshi,1995, p.22). When enough food is supplied to meet the demand for nutrients and assure survival, man becomes concerned with safetysecurity consideration. A person is then, occupied with the problem of the distinction between 'food' and 'poison' in relation to health. The result is that the definition of 'food 'is restricted to those items that are least associated with illness, i.e., those that appear to be lest poisonous and reliably non-toxic. The definition of what is 'poison' is 
expanded to include unfamiliar or strange items and prescribed items (Doshi, 1995, p.23).

For human societies, food is 'the sense of identity which is at the core of human autonomy. The biological need for food and the social act of eating combine to give... a particular meaning, a kind of cultural power' (Simpson, 1996, p. 6; in Rusher, 2003 p. 193). Food as a central element, of cultural values and regional identity is a popular theme and central focus of several tourist destination countries.

It has been said, all social practices can be assessed from a cultural point of view (Johnson, 1986, p. 282). In post- industrial societies food represents more than basic sustenance, and pleasured is placed above need (Finkelstein, 1989; in Everett, 2009, p. 399).

Food is also related with attitudes which varies across cultures. For example, there are important differences in attitudes towards food. For British and Japanese tourists, food is the most important part of the good vacation. For Australians it is ranked third, for Germans it is fifth and for the French food is not at all important (Sheldon \& Fox, 1989; in Reisinger, 2009, p.329). Those from high-uncertaintyavoidance cultures have more negative attitude to pre-cooked food because they are more concerned with the purity and quality of food than those from uncertaintylow-avoidance cultures, who frequently purchase and consume fast food (Demooji, 2004). Cultures also influence eating habits. According to Robertson (1987; Reisinger, 2009, p.329) Americans eat oysters but not snails, French eat snails but not locusts. Zulus eat locusts but not fish; Jews eat fish but not pork; Hindus eat pork but no beef; Russian eat beef, but not snakes; Chinese eat snakes but not people; The Jelas of New Guinea find people delicious! (Reisinger, 2009, p. 329). Here the present author prefers to use Nepalese Hindus eat mutton but not Cow and Muslims eat Cow but not the pork.

In his conclusion, Marriott (1968; in Doshi, 1995, p.16) while employing the attributes of food transaction as a criteria, observes that any transfer of food always makes the giver higher, the receiver lower; suppose that and rendering of service always makes the master higher, the servant lower.

Marriott has worked at local level, that is, village level to find out caste ranking by employed in analyzing and comparing caste hierarchies in "other communities and regions of South Asia." In the context of food ideology, food preferences and food avoidance, what Marriott has found out is important- the relevance of ethnic foods in differentiating a local community. Food types, food status are valuable criteria for assessing ranking of a caste or class society. For instance, in the study of tribal, Status ranking can be made within a group by using the criteria of food production, food consumption, and status food (Doshi, 1995, p.16). 
As suggested by Doshi (1995), the interrelated social function of food in society are as follows:

1. Gastronomic function

2. Means of cultural identity

3. Religious and magic function

4. Means of communication

5. Expressions of economic wealth and status

6. Means of exercising influence and power

Gastronomic function is a part of the science of good eating. The lower segments of society do not appreciate the gastronomic aspects of eating but the higher segments of society eat food not only for biological needs but for pleasure as well. The organoleptic properties of a food can determine whether people accept or reject a food. The pleasure obtained from food is determined by taste, odor, temperature, appearance, structure or texture. The pleasure is related to the community's social psychology and cultural basis. Taste and appreciation of food differs from region to region (Doshi,1995, p. 26).The social aspect of food consumption patterns is that they are a means of cultural identity. It is through the food that people of various segments and classes are identified by the society. Yet another aspect of food and food consumption is related to religious and ceremonial functions. Food is also utilized as a source of communication. The exchange of gifts and serving of food during feasts and other community dinners between individuals and holding of feast among communities on the occasion of birth, marriage and death assumes important function. Meals arranged on such occasions have a strongly competitive element. The economic status of a person also gets expression through food habits and food consumption (Doshi,1995, pp.26-28).

In general, the food consumption, besides satisfying hunger and promoting growth and energy to the body also enhances friendliness and social warmth. It has uses in performing rituals and advancing hospitality. It also helps the consumer to attain status. There are prestigious foods which put a group or an individual on a higher rank in society.

Food has many roles to play for consumers; it is functional (sustaining life); it plays a key role in our celebrations; it is a conduit for socializing; it is entertaining; it is sensuous and sensual; it is a way of experiencing new cultures and countries. For many, food becomes highly experiential (i.e. much more than functional) when it is a part of a travel experience, it can become sensuous and sensual, symbolic, ritualistic, and can take on new significance and meaning. Even the most basic meal can be etched in memory forever when it is eaten when surrounded by awe inspiring 
scenery or at the end of a special day explaining a new city (Mitchell \& Hall, 2003, p. 60).

Food is being accepted as a long-established communication of meaning and can be used as an illuminating focus of theoretical exploration in order to pursue work that recognizes that landscapes are increasingly understood as subjectively experienced and culturally encoded.

\section{Classification of Foods}

Doshi (1995,p.36) in his book, on the basis of secondary sources, has given scientific classification of food. There are 'proximate principle' which explain the main bulk of foods. Proteins, fats and carbohydrates are termed as 'proximate principles', "they are burnt or oxidized in the body to provide the energy for various activities of life. On the basis of these dietary patterns, there has been found cereals, pulses, nuts, oilseeds, vegetables, fruits, milk, milk products and flesh foods as major types found in India.

Frederick J. Simoons (in Doshi,1995,p.37).who has authoritatively written about the food habits in China has classified the food habits of the Chinese on a scientific basis as(1)cereals and pulses;(2)roots and tubers; (3)other cultivated vegetables; (4) seaweeds and other algae; (5) fruits; (6) edible nuts, nut-like fruits, and seeds; (7) flesh and fowl; (8) fish, turtles, and tortoises; (9) eggs; (10) spices and flavorings; and (11) beverages, including dairy products.

There is yet another classification of food given not on scientific principles but on empirical observations by Laura Jane Harper and Maryellen Spencer. They have classified the food commodity groups as: (a) cereals and grains products; (b) starchy roots, tubers and fruits; (c) pulses, nuts and oilseeds; (d) vegetables; (e) fruits (other than starchy); (f) foods of animal's origin; (g) fats and oils; (h) sugars and syrups; (i) spices and other condiments; and ( $\mathrm{j}$ ) other foods not classified above, including yeast, algae and fermented products. The authors observe that dietary patterns within the same culture tend to form specific food groups a useful starting point. It is further argued that the food grouping such as the 'basic seven' (USA) or eight (relating to Chinese culture) have limited application to these culture groups (Doshi, 1995, p. 37).

Passion and Bennett (in Doshi,1995, pp.37-38), who are credited to have worked in southern Illinois of USA, have developed a broad classification of foods as (1) core, (2) secondary core, (3) peripheral foods. Core foods are the universal, regular, staple, important, and consistently used foods. Secondary core foods are foods in widespread use but not universally consumed. They are more variable in use and form, less important emotionally, and include recently introduced packed food bought from provision stores. Peripheral foods are the least common foods, infrequent in occurrence. Their use is characteristic of individual rather than groups. 
One of the reliable criteria of caste or tribal ranking in India is food consumption (Doshi, 1995, pp. 25-26).Food habits in the Hindu ritual system have also been studied by a number of anthropologists. For instance, the practice of offering food to the gods and deities and receiving prasad in return has been analytically examined by Lawrence Bobb (Doshi, 1995, p.15). Bobb observes that the acceptance of prasad indicates the lower position of the devotees as compared to the deity.

One stems from the high Brahmanical (Vaisnavite) tradition of the Indian plain and divides food into three categories: 1) sattvic, 2) rājasic, and 3) tz̄masic. The first is the food of saints. The sattvic diet is strictly (lacto) vegetarian and also regards certain vegetables as impure, e.g., onion, garlic, and radish. The second is the food for kings and warriors. The rājasic food contains meat from goat and chicken as well as eggs. The tzamasic is the food of demons and titans. It permits all the items in the two previous classes, as well as buffalo meat, fermented foods, spirits, garlic, onion, etc., in short, many of the foods which are explicitly excluded from the sattvic and rājasic diets. The underlying conception is that the food determines men's moods and actions. Sattvic food will make a man saintly; rājasic food will make him a ruler or warrior, i.e., powerful and sexually potent; $t \bar{\alpha}$ masic food will make a man an uncontrollable victim of lewd passions, like a demon or a titan. This is a gross simplification. Hindus are well aware that not all people can be saints or kings, but nevertheless it reflects the ideas Hindus have about the effects of food on the state of mind. Newars (of Nepal), as mentioned by Per Lowdin (1998), do apply the idiom expressed in this classification, but only selectively, for instance, at vrta days when the pious observe a fast or, according to this classification, abstain from polluting foods, e.g., meat, garlic, onion, and alcoholic beverages. Sattvic food stuffs are offered to certain deities, notably, to Mahadev and Narayan (Vishnu), who are thought to be vegetarian and who do not accept blood offerings. milk, grains, sweetmeats, etc., which are offered them are later eaten by the devotees as pras $\bar{\alpha} d$. The sattvic food is associated with the Hindu current which regards renunciation of caste and society, abstinence from meat and alcohol, and celibacy as the proper means to attain salvation (Lowdin, 1998, p. 31).

Historically, the role of food in tourism was much underrated, academically and by the travel industry itself. Yet, since travel began food has been a very important element of the tourist experience. Even going back to Chaucer's Canterbury Tales, written at the end of the fourteenth century, food was an essential element of pilgrimage for the characters in the book, and thus an important element of their tourist experience (Povey, 2012, p. 82).

Food tourism studies have been undertaken from a variety of disciplinary perspectives including economics, marketing, regional development, nutrition, economics, tourism, anthropology, psychology and other social sciences. Therefore, it 
is hard to find out accepted definition of food tourism. This reveals that food tourism research is very popular in European countries which have been untouched in Nepal although it has a lot of scope. There are very few authors who have made efforts to collect varieties of Nepalese food and the way of its preparations have certainly given remarkable contributions for introducing Nepal and Nepalese food. This has given birth to kitchen table tourism for replacing arm chair tourism. The present author consulted a lot of materials written by Majupuria (2008), Kansakar (1994), Association of Nepalese in America (1996), Vaidya (1999), Ratnapustak Bhandar (2007) and Pathak (2011). The authors have collected approximately 392 kitchen recipes. The books are the best collection of tested gourmet recipes. Recently, Khanal (2016) has identified 100 ethnic dishes of Nepal. Some anthropologists (Lowdin, 1998; Kunwar, 1999) have also studied on Nepalese food from anthropological perspective which are very useful to know about Nepalese food heritage. But, up till now no one has done research on food tourism or tourism and gastronomy or culinary tourism, slow food, slow city, slow tourism and slow tourist in Nepal. Therefore, realizing the importance of food tourism as a sub-field of tourism, the present author made attempt to highlight on what food tourism is. It is believed that this study will be very useful to the students of tourism and hotel management, restaurants and researchers on one side and those who are involved in farm tourism, agri-tourism and rural tourism, they can also use it as an impetus for developing food tourism in their region.

\section{Food Tourism}

Urry's (2002) 'gaze' privileges the eye; locating other senses in a distinctive visual environment. In claiming the visual has long been understood as the most discerning and reliable sensual mediator between humans and their environment Urry (1992) suggested practices of tourism can be approached with an emphasis on vision. Although the 'gaze' continues to provide a seminal concept for contemporary tourism discussion (Franklin, 2001), particularly those that pursue visual-centric approaches that focus on representations, tangible semiotics and the visual consumption of landscape, it has become apparent that ocular-centric approaches are limited in their ability to tackle the complex dimension of more embodied postmodern activity (Edensor, 2001; in Everett, 2009, p. 341).Since the publication of Urry's The Tourist Gaze (1990), it has become increasingly popular to critique its central theoretical concept of the 'visual' and even Urry himself latterly accepted that the work has often been taken too literally, suggesting that by using the visual sense as a central organizing sense (Urry, 1992) he ultimately favored the dominance of visualism, over after sensory methods of engagement (Everett, 2009, p. 340).

Tourism researchers now acknowledge that there is more to tourism than the visual aspects of the visitor experience epitomized by Urry's "tourist gaze" (1990; in Sims, 2009, p. 321). A growing body of work is beginning to pay testament to the role 
that sensation of taste, touch, sound and smell can play within the holiday (Boniface, 2003; Davidson, Bondi, \& Smith, 2005; Eastham, 2003; Mitchell \& Hall, 2003; Urry, 1995; in Sims, 2009, p. 321), with holiday food becoming of particular importance to researchers ( Cohen \& Avieli, 2004 ; Germann Molz, 2004; Long, 2004b; Torres, 2002; in Sims, 2009, p. 321). More specifically, it is recognized that the kind of foods and drinks on offer for tourists can have major implications for the economic, culture and environmental sustainability of tourism destinations, with researchers arguing that a focus on locally sourced products can result in benefit for both hosts and guests (Sims, 2009, p. 321).

Food has been increasingly regarded as multidimensional, everyday artifact which encompassed the very identity of a place or individual. Eating exotic and global foodstuffs has become part of a new postmodern culture characterized by pluralized and aestheticized experience that have fostered new patterns of tourism consumption and the development of new individualized identities. Food tourism characterizes the 'new' tourism experiences (Poon, 1993; in Everett, 2009, p. 340). Academic studies of tourism and food relationships have examined a range of issues including: caterers' use of local food stuffs (Telfer \& Wall, 1996); competition for land and labor between the tourism and food production sectors (Belisle, 1983); the role of food in destination image (Hughes, 1995); agriculture's role in creating touristic landscapes (Buchgraber, 1996); and tourists' food choices (Reynolds, 1993; in Boyne and Hall, 2003, p. 285).

Food has always been an integral part of tourism but has not received much attention until recently (Hjalager \& Richards, 2002; Hall et al., 2003; Quan \& Wang, 2004; Cohen \& Avieli, 2004; in Keken \& Go, 2006, p.52). Cohen and Avieli (2004; in Keken \& Go, 2006, p.52) consider it even curious that the most bodily of the senses, taste, and more specifically eating and drinking, remained virtually unexplored in the sociological and anthropological study of tourism, notwithstanding their obvious centrality in the experience.

Food is one of the essential elements of the tourist experience. The social and cultural significance of food is finally gaining the recognition it deserves (Cook \& Crang, 1996), as in the role of food in tourism (Hall, 2002; in Hall \& Sharples, 2003, pp. 1-2). Therefore, it is an important element in the marketing of tourism and in determining visitor satisfaction as well as an important component of hospitality studies.

While writing about food tourism, Hall et al. (2003, p. 168) discuss about certain tourism of taste. They summarize the importance of studying food tourism as follows:

1. Food is an attraction in its own right to travel, for mistaking a specific event or a firm like a winery or a brewery, 
2. A particular destination could have a best reputation for certain products, i.e., wine from Tuscany could example of special interest tourism (Hall \& Mitchell,2001),

3. Being part of tourist experience, food has become an important element in the marketing of tourism and in determining visitor satisfaction.

Historically, the role of food in tourism was much underrated, academically and by the travel industry itself. Yet, since travel began food has been a very important element of the tourist experience. Even going back to Chaucer's Canterbury Tales, written at the end of the fourteenth century, food was an essential element of pilgrimage for the characters in the book, and thus an important element of their tourist experience (Povey, 2012, p. 82).

Food tourism should be regarded as an embodied form of tourism, a phenomenon whereby the 'process of experiencing, making sense, knowing thorough practice as a sensual' human subject in the world' is particularly pronounced (Crouch, 2000, p. 68; in Everett, 2009, p. 341). Food tourism may be defined as 'visitation to primary and secondary food producers, food festivals, restaurants and specific locations for which food tasting and/ or experiencing the attributes of specialist food production region are the primary motivating factor for travel' (Hall \& Mitchell, 2001a: 308;in Buiatti, 2011, p. 95). Such a definition does not mean that any trip to a restaurant is food tourism. Indeed such is the need for food to be a primary factor in influencing travel behavior and decision making that as a form of special interest travel, food tourism may possibly be regarded as an example of culinary, gastronomic, gourmet or cuisine tourism that reflects consumers for whom interest in food and wine is a form of 'serious leisure' (Wagner, 2001). Though Everett (2009, p. 338) has also studied on food tourism, his work relates to tourists who make a conscious effort to visit specific food/ drink tourism sites, rather than an exploration of the more generic hospitality sector in tourism....gourmet or culinary tourists who are defined as those tourists whose primary intention to visit a place is connected to taking part in a culinary experience (Murray, 2008; in Stockebrand et al., 2011, p. 29),

With the growing role that food plays in tourism, many researchers have devoted time to the study of the relationship between food and a specific tourism destination, such as food tourism, culinary tourism and gastronomic tourism. Long (1998, p. 32; 2004) defines culinary tourism as 'the intentional, exploratory participation in the foodways of another - participation including the consumption, preparation, and presentation of a food item, cuisine, meal system, or eating style considered to belong to a culinary system not one's own' (pp. 20-21). The concept of "culinary tourism" refers not only to geographical travel for the purpose of sampling foods of foreign lands but also to any journey outside of one's normal dietary routine into the realm 
of the exotic "other" (Chai, 2005, p. 121). Culinary Tourism is ultimately a profitable if perhaps unnecessarily challenging work. It may attract more converts to foodways, a field that successfully mines connections between ordinary and extraordinary, custom and novelty (Camp, 2006, p.379). But when it's time to eat, Culinary Tourism is right on time (Camp, 2006, p. 378).

The term "foodways" suggests that food is a network of activities and systems - physical, social (communicative), cultural, economic, spiritual and aesthetic. Folklorist Don Yodor (1972, p. 325) borrowed the term from anthropologist John J. Honigman (1961) to refer to the total cookery complex, including attitudes, taboos, and meal systems - the whole range of cookery and food habits in a society. As such food touches every aspects of our lives (Long, 1998, FN 4).

According to Long (2004), one can be a culinary tourist when, for example, patronizing local ethnic restaurants, looking through a cookbook, cooking a recipe from another food culture, or walking through a local ethnic grocery store. Long states that "Culinary tourism is more than trying new and exotic foods" (2004, p. 1; in Lockwood, 2008, p. 362).

Regarding gastronomic tourism, Santich (2004) posits that it is 'tourism or travel motivated, at least in part, by an interest in food and drink, eating and drinking' ( $p$. 20; Lin et al., 2011, p.32). Santich further states that gastronomic tourism is about participating in another culture, associated with a particular place and people. According to these explanations of the use of food in tourism, it is apparent that food has the ability to enhance the sustainability and the authenticity of a destination, strengthen the economy of a place and establish the hospitality of a region (du Rand et al., 2003; Everett and Aitchison, 2008; in Lin et al., 2011, p.32).

Buiatti (2011)proposed that food tourism could be defined as 'a visit to food producers with a strong interest in tasting that food and an even stronger motivation to learn about the production process from raw materials to the final product'( p. 95). In the definition of food tourism it is necessary to differentiate between the tourist who consumes food as a part of travel experience and the tourists whose interests, behaviors and even destination choices are influenced and determined by a specific interest in food. Food is obviously an integral part of any travel experience but its importance and significance has been ignored for different reasons: for some travelers it is just a kind of "fuel", for others, who are a growing minority, it is a significant at times the most important reason or motion to travel. Somewhere in between we can find all potential consumers/ tourists who might become the driving force of food tourism (Buiatti, 2011, p. 94).

Food tourism provides a conceptual vehicle for pursuing a more culturally aware tourism agenda. It is suggested that food represents more than purely an economic 
commodity; it is a multi-dimensional cultural artifact capable of linking issues regarding the relationships between place and identity, and the material and symbolic (Everett, 2003, p. 337).Through food tourism it is important to generate economic development that can help preserve natural resources and improve the quality of life of the communities in a region. This ensures that indigenous food and production method are not lost in the globalization (Buiatti, 2011, p. 92).

Many tourists travel to a particular destination which has established a reputation as location to experience quality food products e.g. the Napa valley in California Province in France, Tuscany in Italy, Niagra in Ontario and Yarra Valley in Victoria, Australia (Hall et al., 2003, p. 3; in Hall \& Sharples, 2003, p. 7).

Food tourism is strictly related to the literature on wine tourism which is defined as a tour or visit to wineries, wine festivals and events correlated where the most important motivation for the tourist is to directly experience the characteristic, the quality of a wine through a testing session. The concept of food and wine can be linked to the land and when, for example, the viticulture is successful as it "changes" the local landscape into a mix of tourism, agriculture and industry. Consequently, food/wine production and tourism should rely on regional or local labels/branding for market promotion and in this way the regional/local brand can be an important source of differentiation and a sort of added value for rural region where that particular wine or food specialty is produced. The topic of food specialties is of great interest nowadays and can be considered from different points of view, in particular the relationship between products and territory and the connection between agriculture and tourism. Food is an important part of regional culture and identity and food production has strong impact on the landscape (Buiatti, 2011, p. 95).

Wine, food and tourism are all products which are differentiated on the basis of regional identity. For example, wine is often identified by its geographical origin, e.g. Burgundy, Champagne, Rioja, which in many cases, have been formalized through a series of appellation controls, in turn founded on certain geographical characteristics of a place (Moran, 1993; in Buiatti, 2011, p. 92). Foods, for example, cheese, are also identified by their place of origin. Similarly tourism is also promoted by the attraction of regional or local destinations.

'Food tourists' are the most dedicated group, and local food has an important role in their destination choice. For 'interested purchasers', food contributes to holiday satisfaction and they sample local food when the opportunity arises. 'Un-reached tourists' believe that food can contribute to the enjoyment of their holiday, but they seldom buy local foods. The 'un-engaged' and 'laggards' are those who have limited or no intention to try local food groups (Smith, Macleod, \& Hart Robertson, 2010, p. 78). 
The research carried out by various scholars of different disciplines have been variously examined the interrelationships between tourism and food or food and tourism. The economic, social, cultural and physical impacts also are manifested in tourism food contexts. These impacts can be found in both supply and demand side domains and can be felt simultaneously in both. Some food and tourism initiatives, for example, seek to generate positive outcomes for both the tourism and food production sectors- through increased economic activity - and tourists- by enhancing their visitor experiences (Boyne \& Hall, 2003, p. 286).

Several reasons can be put forward for the growth in attention to food as an area of interest for tourism studies. Since the early 1970s European rural regions are industrialized, societies have been very substantially affected by successive rounds of economic restructuring. In response to loss of services and traditional markets and removal of tariffs and regional support mechanisms, rural areas have sought to diversify their economic base with new agricultural products and tourism being two such responses. Food tourism strategies are therefore a significant instrument of regional development particularly because of the potential leverage between products from the two sectors (Telfer, 2001a).

\section{Sustainable tourism and food}

Research has shown that food is important to sustainable tourism on a number of levels. Firstly, it is argued that increasing tourist consumption of local foods can generate a multiplier effects that will benefit the local economy (Torres, 2002; in Sims, 2009: 320). Secondly, it is concerned about the environmental consequences of transporting food across the global have led researcher to urge that "buying local" is vital if the tourism industry is to reduce its carbon footprint ( Boniface, 2003; in Sims, 2009, p. 322). Thirdly, there is a growing recognition that tourism destination throughout the world are competing each other in a bid to attract visitors. Successful tourist destination must develop a range of goods and services that will distinguish it from other destination and attract a steady of visitors. Promoting high-quality cuisine or distinctive local food products is one way of achieving this (Hage,1997; Hashimoto \& Telfer, 2006; Libery et al., 2003; Woodland \& Acott, 2007; in Sims, 2009 , p. 322). Indeed, local foods may be particularly popular with tourists because they are considered "iconic" products that capture the "typical" nature of a particular place ( Bessiere,1998; Urry, 1990; in Sims, 2009, p. 322).

\section{Food tourism as a form of consumption}

As societies in the West have entered advanced stages of capitalism, 'consumption' has become a central theme of lifestyle. The concept of consumption surpasses the idea of merely buying something to meet basic psychological needs, such as buying a loaf of bread because of hunger. Using social and human psychological perspectives 
associated with consumer behavior studies, it is recognized that by purchasing a certain good or service, a range of needs may be met that go beyond our most basic biological requirements. (Holden, 2008, p. 42)

Sociologists emphasise that through the process of consumption, it is possible to the differentiate oneself from the crowd, and subsequently gain a sense of identity. Being linked to consumption was a theme developed in the late nineteenth century by the American sociologist Thorstein Veblen (1899; in Holden, 2007, pp. 35-36). Veblen's work was based upon observation of the newly emerging wealthy middle class in America, who were making considerable amounts of money from trade and manufacturing. In what was a critical account of their lifestyle, Veblen coined the phrase 'conspicuous consumption', to explain how this class used leisure and consumption to differentiate themselves from the rest of society. Through the purchasing of goods and other ornaments and services, they took on a different identity from the rest of the populace, who could not economically afford to purchase these products. By the end of the nineteenth century, tourism also offered a form of consumption, which permitted social differentiation. Within what was a predominantly patriarchal society, by sending one's wife or daughter on holiday from America to Europe, the massage was conveyed that one possessed wealth. (Holden, 2007, p. 36)

Using tourism as a means to achieve social differentiation has become increasingly prevalent in western society. Mowforth and Munt (1998) use the term 'habitus', borrowed from the French sociologist Pierre Bourdieu, to suggest that the types of tourism we participate in carry cultural symbols and meanings. Habitus refers to the ability and inclination of individuals and social classes to adopt objects and practices that differentiate them others in society. Although the ability to participate in international tourism in contemporary society fails to achieve social differentiation as at the time of Veblen, yet where we are able to go and what we choose to do on holiday carries cultural messages and differentiates us from others in society (Holden, 2008, p. 44).

The link between urbanization consumption and tourism has been developed by both Boorstin (1992; in Holden, 2008, p. 44) and MacCannell (1976) to explain why people choose to travel.

\section{Methodology}

For the first time, the present researcher wrote a review paper on food tourism that was published in this same Journal of Vol. 3, 2011. At this moment, the researcher thoroughly reviewed the articles of food tourism and gave the title food tourism revisited. Methodologically, the study is based on secondary sources. The scholars of food tourism have suggested to follow transdisciplinary perspective (Scarpato \& Daniele, 2003), multidisciplinary perspective (O' Gorman, 2010) and interdisciplinary perspective (Visentin, 2011). Interdisciplinary is not the mere merging of different 
disciplines- is called into account to shed light from its specific perspective onto the subject of study. Rather interdisciplinary is a means to identify and study new themes that single disciplines would not be able to put in to focus, describe interpret by themselves (Visentin, 2011, xiii).

The reviewing of past research efforts facilitates an improvement and understanding of research and reveals the philosophical, conceptual, substantive and technical problems of research in a field (cited from Backman \& Morais 2001). Certainly; this approach can be linked in the study of food tourism as studied by previous researchers.

\section{Gastronomy}

"Eating is an agricultural act", (Wendell Berry, the American poet, farmer by profession born in 1934).It follows that producing food must be considered a 'gastronomic act' (www.slowfood.com). Gastronomy tourism refers to trips made to destinations where the local food and wine beverages are the main motivating factors foe travel. (www.onecaribbean.org).

It is time for the tourism academy to move food tourism out of the 'grey zone' of cultural and heritage and knowledge its conceptual opportunities (Scarpato, 2002; in Everett, 2009, p. 339). Notably, it has been suggested that the wider body of research on relationship between food, society, culture and the economy is 'tainted by a missing gastronomic perspective (Scarpato, 2002, p. 60; in Everett, 2009, p. 339). Scarpato argues that the contribution of gastronomy studies to tourism discourses remains surprisingly untapped as it offers an innovative conceptual framework that can contribute significant new dimensions to tourism research. Consequently this article embraces food tourism as a multi-dimensional vehicle that can highlight the richness and diversity characterizing the way tourism studies is evolving into a more critical social science open to cultural interpretation. In particular, it can contribute to further understandings of the dimensions and complexity of postmodern forms of consumptive activity. After all, the notion that food and drink might serve as a central organizing for anyone studying the world of humankind seems to have eluded virtually all social scientists, but, after a bit of reflection, it does make abundant good sense (Zelinsky, 1985, p. 51; in Everett, 2009, p. 339).

Most current dictionary definitions of gastronomy still emphasize the 'science' aspect defining gastronomy in terms of the art and/or science of good or delicate eating. While it might be possible to translate art and science as skill and knowledge and thereby demonstrate a continuity and consistency with the early nineteenthcentury understanding, most contemporary interpretations of gastronomy seem considerable narrower than that of Brillat-Savarin, who considered gastronomy to pertain to a range of disciplines including natural history, physics, chemistry, 
cookery, commerce and political economy (Brillat-Savarin, 1994; in Santich, 2007, p. 48).

Brillat-Savarin demonstrated that his understanding accorded with the etymological origins of the term, which derives from two ancient Greek words: gaster [the stomach and, by extension, the digestive system] + nomos [rule or regulation] (Brillat-Savarin, 1994; Richards, 2002; Stierand, 2013, p.50) or 'nomon' (Stierand, 2013 , p. 50). Thus gastronomy can be seen as relating to rules associated with eating - what, where, when, why, how and with whom. The 'science' of gastronomy enables the elucidation and understanding of these rules, which in turn serve as the basic for the guidance. Significantly, Brillat-Savarin's understanding of gastronomy is also consistent with the intentions of Archestratus, possibly the first person to use the word. (Archestratus was a Sicilian Greek who lived in the fourth century BC and who wrote probably the earliest food and wine guide to the Mediterranean region - what was best to eat and drink and where to find it; Gastronomia is one of several putative titles to this book) (Wilkins \& Hill, 1994; cited in Santich, 2007, p. 48).

A concise definition of 'gastronomy' is notoriously elusive. The interpretations given in a recent text, European Gastronomy into the $21^{\text {st }}$ Century, echo the standard dictionary definitions: 'the art, or science, of good eating', 'the enjoyment of food and beverages', 'the enjoyment of good food, and good beverage, in good company' (Gillespie, 2001; in Santich, 2007, p. 48). A recent article in a popular French magazine described how to transform 'cuisine' into 'gastronomie', thus implying that gastronomy is in some way special or superior, either by the cost of quality of the ingredients, by the preparation methods or techniques or by the care and time devoted to the finished dish. (Ironically, the idea of transforming an ordinary dish or meal into a special one also implies sleight-of-hand tricks specifically designed to deceive the eater.) Such 'elitist' interpretations tend to associate gastronomy almost exclusively with restaurants and restaurant cuisine (Santich, 2007, p.48).

When Gillespie adds that gastronomy is 'also an examination of the terms "good food" and "good wine" (or other beverages), and "in whose terms", the 'terms' suggested relate specifically to restaurant situations (2001; cited in Santich, 2007, p. 48). While this narrow interpretation might seem appropriate in the context of restaurants and commercial hospitality, it is inadequate to represent the potential depth and breadth of gastronomy (Santich, 2007, pp. 48-49). In hospitality and hospitality management, however, the term 'gastronomy' is more narrowly associated in the Western world gastronomy and haute cuisine as matters of economic and cultural significance, as a result of which established and elaborate culinary practices and aesthetics have globally influenced chefs and the hospitality industry for over 400 years, an influence recognized in 2010 when UNESCO (United Nations Educational, Scientific and Cultural Organization) added the gastronomic meal of the French to 
its 'Representative List of the Intangible Cultural Heritage of Humanity' (UNESCO, 2010; Stierand, 2013, p. 50).

It is significant that Brillat-Savarin does not specially refer to food and drink in his definition of gastronomy, but rather to everything that relates to our nourishment ('...insofar as we sustain ourselves'). Thus the focus of gastronomy is not so much food and drink per se, or even meals, but our eating of food, our drinking of beverage - in other words, consumption. To the extent that this is a convivial rather than a solitary activity, gastronomy therefore extends to sociability and communication. While gastronomy necessarily refers to food and drink, what is more important is their place in human societies and how human societies produce, prepare, classify and value food and drink - in other words, the norms, explicit or implicit, which are understood and accepted by the culture in which they originate and which apply to such concepts as mealtimes and contents of meals, to the values associated with foods, to the ways foods are produced and to food and beverage partnering. Ferguson (1998; cited in Santich, 2007, p.49) has proposed that gastronomy be considered a 'cultural field' which includes not only the 'culinary products, but also an understanding of the 'practices and products, values and behavior, rules and norms, institutions and ideas that are attendant upon the preparation and consumption of food' in particular social setting (Ferguson, 1998; cited in Santich, 2007, p.49).Since the fifteenth century, led by the French, European gastronomy and haute cuisine has witnessed three distinct culinary eras: the ancient regime, classical cuisine and nouvelle cuisine. In the culinary world this led slowly but steadily to the development of a new style of cuisine - nouvelle cuisine - that crystallized as a distinct phenomenon in the early 1970s (Rao et al., 2003; in Stierand, 2013, p.52).The underlying philosophy of nouvelle cuisine was based on four values: truth, lightness, simplicity and imagination ( Rao, 2009, p.86; in Stierand, 2013, p.52). Chefs started to question established culinary conventions and created new dishes by using the concepts of transgression and acclimatization. Transgression meant that old cooking techniques were combined with new ingredients, or old cooking techniques were combined with old ingredients in hitherto unacceptable ways, such as combining fish with meat or salads with foie grass. Acclimatization, on the other hand, meant adopting foreign cooking traditions, in particular through employing exotic spices and seasoning (Fischler, 1993; Rao et al., 2003; in Stierand, 2013, p. 52). In this sense, nouvelle cuisine introduced a more contemporary and self-expressive way of cooking.

At present there is much debate over whether we are entering a fourth era, of molecular cuisine, or avant-garde cuisine (Stierand, 2013, p.51). Another root for creativity to become accepted as a concept in culinary practice was laid by the Oxford physicist Professor Nicholas Kurti, who was interested in applying science to solve problems in the kitchen. In 1988, together with physical chemist Herve This (2006b) 
founded a new branch of food science under the name of molecular and physical gastronomy (This, 2006a; cited in Stierand, 2013, p. 52). This name derived from a series of workshops about the physics and chemistry of cooking run by both scientists. In 1998, however, Herve This (2006b; cited in Stierand, 2013, p. 52) decided after the death of Nicholas Kurti to use the simpler term molecular gastronomy that he had always favored (This, 2006b; cited in Stierand, 2013, p. 52). The basic intention of molecular gastronomy is to better understand the 'chemistry and physics behind the preparation of any dish' in order to gain knowledge that can help to produce healthier, more attractive and better food (This, 2006a:1062; in Stierand, 2013, p. 52).

Unfortunately, the term molecular gastronomy became fashionably misused by both the media and some chefs who, straining after effect, pursued a form of largely excessive hyper-creativity that took shape in such dishes as strawberry risotto with salmon and tended to emphasize the aesthetic (especially the photogenic) appearance of food over taste (Stierand, 2013, p. 50).

Gastronomy today relates to 'the production of food, and the means by which foods are produced; the political economy of food; the treatment of foods, their storage and transport and processing; their preparation and cooking; meals and manners; the chemistry of food, digestion and the physiological effects of food; food choices and customs and traditions' (Santich, 2007, p. 49).

Gillespie's focus on the material aspects of food and its preparation, typically in a restaurant context, not only places unreasonable limits on the domain of gastronomy but overlooks the crucial roles of the critic, the guide, the adviser, roles which were pioneered in the nineteenth century by Grimod de la Reyniere and Brillat-Savarin (Santich, 2007, pp. 49-50).

Food is an important place-marker in tourism promotion. The climatic conditions, culture and history of a region shape the character of the food that is produced. Gastronomy is often said to be a sub-sector of cultural or heritage tourism for this reason. This link between location and gastronomy has been used in a number of ways in tourism, including promotional efforts based on distinctive or 'typical' regional or national foods. Food can also be used as a means for guiding tourists around regions and countries, for example in the form of trails (Hjalager \& Richards, 2002; in Smith, Macleod, \& Hart Robertson (2010, p.77).

Hall and Mitchell (2005a; in Smith et al., 2010, p. 78)suggest categorizing gastronomic tourists as follows:

- Gourmet tourists- visit expensive or highly rated restaurants or wineries

- Gastronomic/ culinary tourists- interested in wider issues such as the culture and landscape which produce food and wine 
- Cuisine tourists- interested in specific cuisines from a country or region.

Gastronomic tourists (like most special interest tourists) tend to be wealthier and better educated than average travel without children, and are usually in the $A B$ (upper/ middle) or CL (lower-middle-class) groups (Smith et al., 2010, p.78).

Hall and Mitchell (2005a; in Smith et al., 2010, p.78) state that only 3 per cent of international tourists could be described as gastronomic tourists, but Enteleca Research \& Consultancy (2000) provided an analysis of tourists which implies that far more tourists enjoy gastronomy as a secondary motivation and could therefore be targeted by food producers or suppliers:

- Food tourists (6-8\%)

- Interested purchasers (30-33\%)

- The un-reached (15-17\%)

- The un-engaged (22-24\%)

- Laggards (17-28\%)

'Food tourists' are the most dedicated group, and local food has an important role in their destination choice. For 'interested purchasers', food contributes to holiday satisfaction and they sample local food when the opportunity arises. 'Un-reached tourists' believe that food can contribute to the enjoyment of their holiday, but they seldom buy local foods. The 'un-engaged' and 'laggards' are those who have limited or no intention to try local food groups (Smith et al., 2010, p.78).

Erik Wolf (2008; in Smith et al., 2010, p.78), president of the International Culinary Tourism Association, a non-profit group representing more than 500 tourism businesses in 19 countries, described how World Travel market Research had revealed that more than half (53 per cent) of tourists ranked eating traditional dishes as a 'very important' or 'important' part of their holiday. Of British people, 86 per cent said they enjoyed local foods when abroad and would skip meals in the hotel or resort to try out local restaurants. This implies that the latent demand for gastronomic tourism could be much higher than previously thought (Smith et al., 2010, p. 78).

For neophilic tourists, eating new foods is a fundamental element of the travel experience, while for others it can be a reinforcement of feelings of 'not belonging' (Veek, 2010; in Povey, 2012, p. 83).

For the postmodern tourist, food and gastronomy is increasingly fundamental to their identity formation (Ignatov \& Smith, 2006; in Povey, 2012, p. 83). This is reflective of the central role of food in culture, where food is literally grown out of the 'terroir'- the soil and climate of the region. Tourists consuming locally grown 
products literally consume the destination and its culture in the flesh (Povey, 2012, p. 83).

According to Buckland (2007; in Povey, 2012, pp. 83-84), tourists who aspire to experience authenticity ascribe high value to the authenticity of their gastronomic experience. There is triumvirate relationship affecting the authenticity of any meal, which is an interaction between. 'The Self' and the sum of their experiences, 'The Thing' that is actually being experienced and 'The Others', which is the ways in which authenticity is defined by societies (Beer, 2008; in Povey, 2012, p. 84).Another key aspect of gastronomy's relationship with tourism is in the area of heritage food. Heritage attractions now often features kitchens, and focus more on the lives of servants and ordinary people than on the leisured classes and aristocracy. Consumption of heritage food is linked to the consumption of place and the value of old British pubs, many of which are heritage attractions in themselves, and the food served therein (Howe, 1996; in Povey, 2012, p. 85), as well as the significance of historically valuable restaurants or 'historant'. Josiam et al. (2004; in Povey, 2012, p. 85) explored this relationship, where actual consumption of heritage could take place.

According to Buckland (2007; in Povey, 2012, pp. 83-84), tourists who aspire to experience authenticity ascribe high value to the authenticity of their gastronomic experience. There is triumvirate relationship affecting the authenticity of any meal, which is an interaction between. 'The Self' and the sum of their experiences, 'The Thing' that is actually being experienced and 'The Others', which is the ways in which authenticity is defined by societies (Beer, 2008; in Povey, 2012, p. 84).

Another key aspect of gastronomy's relationship with tourism is in the area of heritage food. Heritage attractions now often features kitchens, and focus more on the lives of servants and ordinary people than on the leisured classes and aristocracy. Consumption of heritage food is linked to the consumption of place and the value of old British pubs, many of which are heritage attractions in themselves, and the food served therein (Howe, 1996; in Povey, 2012, p. 85), as well as the significance of historically valuable restaurants or 'historant'. Josiam et al. (2004; in Povey, 2012, p. 85) explored this relationship, where actual consumption of heritage could take place.

As global competition tourist destinations increase the search for distinct products becomes more intense. Gastronomy is seen as an important source of marketable images and experiences for the tourists (Richards, 2004, p. 4; cited in Keken \& Go, 2006, p. 56). Richards emphasizes that food has become an important factor in the search for identity. Food is one of our basic needs, so it is not surprising that it is also one of the most widespread markers of identity. We are what we eat, not just in a 
physiological sense, but also in psychological and sociological sense as well. Food has been used as a means of forging and supporting identities, principally because what we eat and the way we eat are such basic aspects of our culture (Richards, 2002, p. 5; cited in Keken \& Go, 2006, p. 56).

\section{Slow Food Movement}

Those who have studied on food tourism in relation with gastronomy and culinary tourism, they have also focused on slow food tourism. The notion of 'fast' in fast food deserves an extra attention in this context because often it is connected with modern (Western) life, which is, young, dynamic, and energetic. Everything needs to happen 'fast'. Although, a reversed trend in this respect can be seen by those people who worry about all this speed and ask for reflection, distressing, slowing down. "An often-brought-up example is the Slow Food Movement that started in Italy in 1989 from Bra, a small city in the North West of Italy, alongside the Langhe wine district and near to the Alba tourist region" (Heitmann, Robinson \& Povey, 2011, p. 114).

During an anti-McDonald's protest in Rome 1986 the term 'Slow Food' was coined as a rally called for those who wanted to halt the invasion of standardized .A second influence on the formation of movement was the death of 19 Italians who drank cheap wine that had been mixed with methanol. In reaction to these event, Carlos Petrini formed the embryonic slow food movement, which was officially launched in December 1989 in Paris. Since then the movement has gone from strength to strength, and now has 100,000,members from 132 countries worldwide (Slow Food, 2010; in Heitmann et al., 2011, p. 115; Rombach \& Bitsch, 2015, p. 2).

Slow Food is a non-profit, member supported eco-gastronomic organization which was founded in 1989 to counteract fast food and fast life ,the disappearance of local food traditions and people's dwindling interest in the food they eat, where it comes from, how it tastes and how food choices affect the rest of the world (Santini et al., 2011, p. 165).

Slow food is philosophically centered on the rights of all citizens to enjoy clean (unpolluted), fairly traded food that has been sustainably produced with consideration for all stakeholders, including the being eaten and the planet itself (Heitmann et al., 2011, p. 115).

Slow food is a counterbalance to what a French sociologist Fischler calls 'gastro anomy' (Beardsworth \& Keil, 1997; cited in Keken \& Go, 2006, p. 52) referring to massiveness of food supplies, the abundance of food and has nothing to do with meat products, technologization of food or the publicity overload for consumers. In 1989 Jacques (Hall \& Mitchel, 2002, p. 82; cited in Keken \& Go, 2006, p. 52) observed already that there is a new search for identify and difference in the face of impersonal 
global forces, which is leading to the emergence of new national and ethnic demands. Tourism is a part of the search for identity and a desire for economic positioning in contemporary globalization. Tourism and food provides identity in terms of provision of the 'other' and in terms of self-reference (Keken \& Go, 2006, p. 52).

The Slow City, Cittaslow or Citta Lenta movement is a spin-off of the slow food movement. It has variously been defined as an urban social movement and a model for local governance (Pink, 2008: Heitmann et al., 2011, p. 116).The slow city movement seeks to extend the slow food movement's philosophy to all aspects of urban living providing an agenda of local distinctiveness and urban development (Heitmann et al., 2011, p. 116).

Following slow food and slow cities, the movement has been extended further to other aspects of society and living. The slow movement provides the ideas on how the concept of slow can be applied to education, books, money and living. How the concept is adapted to travelling and tourism will be outlined further below however, central to all of these applications is addressing the issue of time poverty and fast solutions by encoring more through connections to people, places and life (Heitmann et al., 2011, p. 117).

That puts taste first, and also has started the movement 'Slow Cities'. Slow food stands for traditional, original, delightful, diversity and quietness and is of course the opposite of the fast world. The goal of the slow food movement is to rediscover the richness and taste of the local kitchen and fight against standardization. According to Carl Honore (2004; cited in Keken \& Go, 2006, p. 51), this slow food movement is part of a bigger movement that propagates slowness in all parts of our daily lives. In his book 'In praise of Slow, how a worldwide movement is challenging the Cult of Speed' he describes how in our Western world there is a growing dissatisfaction with our way of life, the 24-hour economy.

Erik Wolf (2008; in Smith et al., 2010, p. 78), president of the International Culinary Tourism Association, a non-profit group representing more than 500 tourism businesses in 19 countries, described how World Travel market Research had revealed that more than half ( 53 per cent) of tourists ranked eating traditional dishes as a 'very important' or 'important' part of their holiday. Of British people, 86 per cent said they enjoyed local foods when abroad and would skip meals in the hotel or resort to try out local restaurants. This implies that the latent demand for gastronomic tourism could be much higher than previously thought (Smith et al., 2010, p. 78).

Like tourism, food consumption should be treated as an encounter that flirts with space and contributed to a postmodern landscape saturated with meaning and diversity (Crouch, 1999); demanding a place in the rapidly shifting nature of tourism studies (Everett, 2009). 
Garrod, Wornell and Youell (2006; in Santini et al., 2011, p. 167) illustrate the role of country side capital (landscape, biodiversity, historical features, distinctive local customs and way of life, etc.) in the development of sustainable rural tourism. The authors emphasize how rural tourism businesses and destinations exploit countryside resources to attract tourists and after them fulfilling experiences during their journey.

While writing about wine tourists, Johnson (1998, p. 15) has classified two types of wine tourists: specialist versus general tourist. The general tourist is 'one who visits a vineyard, winery, wine festival or wine show for the purpose of recreation', and the specialist wine tourist is 'one who visits a vineyard, winery wine festival or wine, show for the purpose of recreation and whose primary motivation is a specific interest in grape wine or grape wine related phenomena. This typology can be directly applied to food tourists with Lang Research's (2001) 'high cuisine and wine interest' tourists the most likely to be the specialist food tourist (Mitchell \& Hall, 2003, p. 69). Lang Research found that few American (19.6 percent) or Canadian (14.2 percent) tourists fell into this category...

Gourmet tourism addresses its offer to a small number of selected tourists, whose main interest for travelling is tasting specialty foods or wine in selected restaurants or wineries. On the contrary, the phenomenon of rural tourism involves a wider number of tourists whose interest in food could be secondary or subsidiary to other interests: this is the case with while visiting a certain rural area. The scheme summarizes many facts of food tourism and describes the relationships that rural tourism has with food and furthermore it provides a clear idea on differentiation in food tourism. Terror products can be conceived as a synthesis of production processes based on local resources which directly link, case by case, though in different ways, the product to the territory. In this way, the product is a harmonious bundle of territorial, climatic, historical and cultural characteristics which belongs to a certain region (Arfini, 2005; in Santini et al., 2011, p. 168). This kind of product becomes the cultural marker of a territory and the identity and image of this product provide leverage for the development of the general welfare of the population living in the specific region.

Aurier et al., (2005; in Santini et al., 2011, p. 167) identified three dimensions, cognitively describing terroir products in the customer's mind:

Trade - skill, including the categories know how recipes and tradition

Time and culture, including categories history and ritual

Origin, including the categories territory, region and land.

While food is an important part of regional identity and food production does have substantial impact on the landscape it is very difficult to separate foodscapes from broader 
concerns surrounding agricultural areas which by their very nature are landscapes of food production. Therefore, the geographical setting, climatic conditions, temperature, seasonal, environmental conditions and places are also important in food tourism. Indeed, one of the critical factors in food tourism is the spatial fixity of the product.

Relph (1996) has suggested that tourism is fundamentally about the difference of 'place. Clearly a region's physical element combine to define it as a 'place' and contribute to the attractiveness of a destination. Similarly, Cook and Crang (1996, p. 132) identify the importance of place as a means of differentiation: 'These geographical knowledge - based in the cultural meanings of places and spaces- are then deploys in order to "re-enchant" (food) commodities and to differentiate them from the derived functionality and homogeneity of standard products and places.' Perhaps not surprisingly then, Hall (1996: 114) suggests that there is a significant overlap between the elements of terroir and those features that are important to regional tourism branding (e.g. landscape and climate). Hall and Mitchell (2002b: 69), for example, discuss the idea of 'touristic terroir', arguing that 'In the same way that the terroir of a region gives wine its distinctive regional characteristics, the unique combination of the physical, cultural and natural environment gives each region its distinctive touristic appeal- its touristic terroir' (Hall et al., 2003, p. 34).

Important as this notion of touristic terroir is in determining the flavor of the wine and food tourism experience, it is important to note that, like wine, terroir is not only influence on flavor. As the late Peter Sichel (former president of the Grand Crus de Bordeaux) suggests 'terroir determines the character of wine.... Continuing the wine and food analogy, then, touristic terroir may determine the character of the regional experience, but it is the influence of the tourism entrepreneur, the winery owner, restaurant manager, chef, service provider or regional tourism office that will determine the quality of the experience (as attested the large number of visitors who cite service as the most enjoyable or important aspect of visits to wineries (Hall \& Mitchell, 2002b).

Networks and cluster relationships are also a significant part of the development of intangible capital through their role as proving the social capital which underlies much economic development. A cluster is defined as a concentration of companies and industries in a geographic region that are interconnected by the markets they serve and the products they produce, as well as the suppliers, trade associations and educational institutions with which they interact (Porter, 1990; in Hall et al., 2003, p. 37). Such exporting chains of firms are the primary 'drivers' of a regional's economy, on whose success other businesses, construction firms for example, depend in terms of their own financial viability. An industry cluster includes companies that sell as well as outside the region, and also supports firms that supply raw materials, components and business services to them. These clusters form 'value chains' that are the fundamental units of competition in the modern, globalised world economy. Firms and organisations 
involved in clusters are able to achieve synergies and leverage economic advantage from shared access to information and knowledge networks, supplier and distribution chains, markets and marketing intelligence, competencies and resources in a specific locality (the cluster concept focuses on the linkages and interdependencies among actors in value chains (Enright \& Roberts, 2001; in Hall et al., 2003, p. 37).

Cluster formation is regarded as a significant component in the formation of positive external economies for farms, including those of the wine industry, with tourism being recognized as a significant component (Porter, 1990), While Telfer (2000a) has argued that cluster development has been a significant component of wine and food tourism network development in the Niagara region of Canada. Although one of the lessons cluster development programs around the world is that there is no precise, "right" (one size fits all) formula for developing industry clusters' (Blandy, 2000, p. 80; in Hall et al., 2003, p. 38), a number of factor has been recognized as significant in the development of clusters and the associated external economy which serves to reinforce the clustering process.

It is necessary that the traditional tourism activities in particular those specialized in food tourism develop a sensitivity to protect and integrate with the natural cultural resources available in territory. Through food tourism it is important to generate economic development that can help preserve natural resources and improve the quality of life of the communities in region. This ensures that indigenous food and production methods are not lost in the face of globalization (Buiatti, 2011, p. 92).

However, studies of food tourism are largely limited to food safety and hygiene issuesv (MacLaurin, 2001), analyses food and wine festival attendance (Pratt, 1994), supply - side issues such as business networks (Hall \& Johnson, 1998), food production and tourism (Telfer \& Wall, 1996) and cross promotion between food and tourism (Mitchell et al., 2001) or the impacts of tourism on regional or national cuisine (Hall \& Mitchell, 2001). Even more established disciplines studying the 'human element' of food consumption such as anthropology, sociology or cultural studies have done little to explore the consumptive experiences of tourists. As far as consumer behavior is concerned, Mitchell et al. (2000, p. 118) suggested that: consumer behavior research is important for stakeholders in wine tourism because it can help provide important insights into who the wine tourist is, what motivates them to visit a winery, take a guided tour, attend a wine festival or purchase wine and why, thus allowing marketers and managers to effectively target and develop market. Same can also be said of food tourism stakeholders such as restaurant and café owners, cookery school providers, festival organizers, hotel and resort managers, bed and breakfast operators, and food producers.

Consumer behavior research is the study of why people, either individually or in groups, buy the product and they do and how they make their decision (Swarbrooke 
\& Horner, 1999). Such research therefore examines a range of internal (motivation, attitudes, and beliefs, learning, life styles and personality) and external (demographics, reference groups and culture) influences on decision making (purchase decision, choice, brand awareness and loyalty, evaluation and post-purchase decisions) and, more recently, the consumption experience (the occasion, consumption setting and benefits gained from the experience). Research on consumer behavior is interdisciplinary, drawing on concepts and theories and such fields as psychology, sociology, social psychology, marketing, cultural anthropology, economics, media studies, cultural studies and geography (Bell \& Valentine, 1997; in Mitchell \& Hall, 2003, pp. 61-62).Further, some tourism authorities have undertaken research that includes eating out as an activity for various segments of the travel market.

Of course a tourist is, first of all, a consumer, and from the consumer perspective the concern about the quality and safety of food he/she can find on shelves and in restaurants becomes stronger every day, especially after the BSE (Bovine Spongiform Encephalopathy) crises, the foot and mouth outbreak in 2001 and the more recent avian or "bird" flu. Also very important is the recognition by "green" consumers of the impact that long distance food transport can have on the environment (this is so called "food miles"). This has led to a growing interest in organic and natural products, and the importance of food traceability and, hence, an increasing demand for locally sourced food. The preservation of the countryside as a source of relaxation and rest is a fundamental issue both for the tourist/consumer and the tour operators that benefit from it. Also important is to regard the tourism and the maintenance of landscape as an important potential solution to sustain the social life of people that live there, creating productive activities and employment (Buiatti, 2011, p. 94). The local people could play the role of guardians of landscape or environmental architects" (Roberts \& Hall, 2001; in Sidali; 2011, p. 7).

How can a territory, a region, a village and their food specialties, be linked to tourism? Most-potential visitors to Italy want to taste traditional dishes, regional specialties, and fresh local produce, possibly organically grown. Food is an important economic and cultural resource offering tangible benefits for tourism. Nepal is one of the most popular tourist destinations of South Asia where more than half million tourists taste Nepalese food i.e. dal, bhat, tarkari and achar ( rice, lentil soup, green vegetable and pickle). However, if it is essential that people involved in this activity are effective in delivering an authentic food experience to an increasingly aware and health conscious group of visitors.

The linkages that exist between food, the landscape or place that the food has strong associations with, and tourism have started to form the basis of an interesting academic debate in recent years. For examples, Reynolds (1993; in Sharples, 2003, p. 206) discusses the importance of preserving traditional food as an essential part 
of sustainable tourism, Telfer and Wall (1996) comment on the linkages that exist between tourism and food production, Hall and Mitchell (2000) debate the role of cuisine as a factor in globalization and localization and Hjalager and Corigliano (2000), examine the development of food standards for tourists. Part of this important debate is the concept that local food can form an essential and innovative part of a regional tourism marketing strategy and this argument is now gaining ground (Sharples, 2003, pp. 206-207).

As Levi-Strauss (1978, p. 471; in Scarpato \& Daniele, 2003, p. 297) pointed out 'Cooking....is with language a truly universal form of human activity'. But, Bell and Valentine (1997; in Hall \& Mitchell, 2003, pp. 75-76) have suggested that 'kitchen table tourism' has replaced 'arm chair tourism' as a form of vicarious exploration, where eating at ethnic restaurants, cooking from ethnic cook books and watching food and travel television shows (often sponsored by local and national tourism organizations) allows us to travel without leaving our home, town or city.

In tourism, the notion of risk is related to one of the key motivating factors for pleasure travel-novelty seeking. High risk-takers (and therefore those with degrees of involvement) see extremely novel environments and situations. Plog (Ross, 1994; Mithcell \& Hall, 2003, p.76; in Kunwar, 2017, pp. 52-55) has suggested... allocentrics seek most novel/new environments and psychocentrics seek familiar and less threatening vacations settings. The work of Plog suggests that allocentrics are naturally neophilic (literally they 'love new/ novel' phenomena), while psychocentrics are neophobic ('fear of new/ novel'). Neophilia is also widely discussed within food literature, where it is suggested that human omnivorous behavior is a paradox between neophilic and neophobic tendencies (Bell \& Valentine, 1997; in Hall \& Mitchell, 2003, p. 77). Tuorila et al. (1994; in Hall \& Mitchell, 2003, p. 77) suggest that neophobia in food consumption results in those with neophobic tendencies disliking novel looking, smelling and tasting foods. In contrast, Bell and valentine (1997) have suggested that the development of 'new cuisines' and the globalization of national cuisines around the world has relied on neophilic tendencies and that travel has long involved food neophilia as an important motivator (e.g. grand tours). Neophilia and involvement are, therefore, important concepts in the discussion of the food tourism experience. They provide an insight into some of the experiential differences observed in food tourism consumer behavior (Hall \& Mitchell, 2003, p. 77).

The phases of the food tourism experience conceptualized here are: eating at home (pre-travel); eating out (pre-travel) advocated above as a form of vicarious exploration that is different to eating at home; food at the destination; vacation experiences at the; destination advocated by Mitchell, Hall and McIntosh (2000: in Mitchell \& Hall, 2003, p. 77) as important influence on the on-site visit in this case food tourism; \& food (post travel experiences). 
Figure: Food tourism as special interest tourism

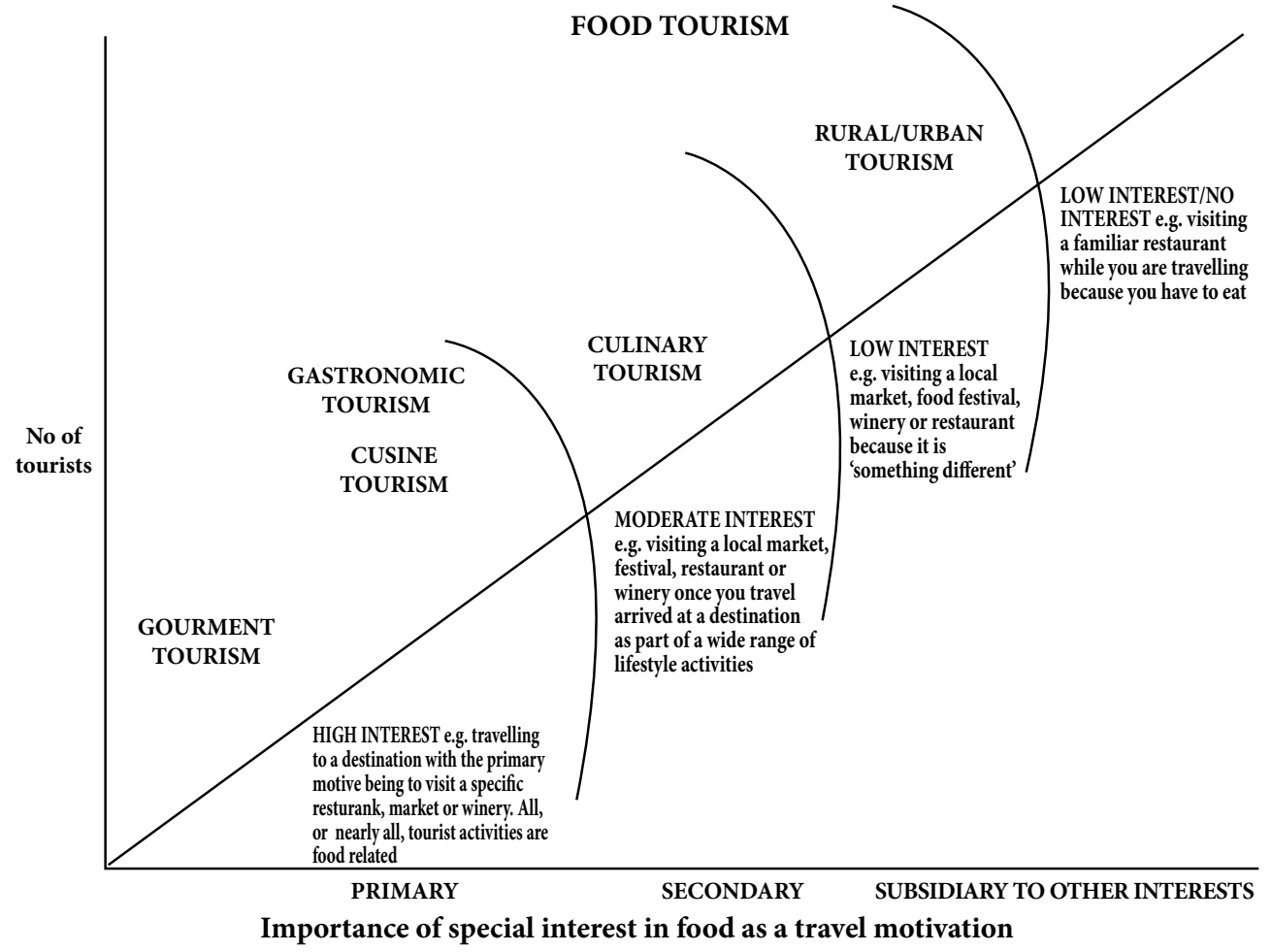

Source: Hall \& Sharples, 2003, 11

It is being increasingly acknowledged that there is a need to embrace wider and more active bodily involve (mental, physical, intellectual, cognitive and the gaze) (Franklin, 2001). The recently theorized concept of 'performance' (as opposed to gaze) notably proposed by Edensor (2001) and Perkins and Thorns (2001), has become an attractive alternative approach that widens the concept to embrace the more multifaceted, multisensory experience that make up tourism such as adventure (Clock \& Perkins, 1998) and sex tourism (Ryan \& Kinder, 1996).Although Urry had never denied the existence of multiple gazes in his earlier work, he was kin to state a decade later that 'I think there is a multiplicity and the way to approach the analysis of these multiplicities of tourist gaze is, among other things, to think about the taste-scapes, smell-scapes, sound scapes, touch-scapes' (Franklin, 2001, p. 123; in Everett, 2009, p. 341). Everett (2009) suggests that food- and drink- focused tourism studies offer a more fascinating lens through which to examine these more heterogeneous sensory landscapes and theorize whether they offer different 'kinds' of non-representable knowledge (Crouch et al., 2001). There is a need to address 
the ontological blind spot where 'little so far has been understood about how the metabolic material and fleshy connections consumers make with foodstuff inform their embodied knowledge (Roe, 2006, p. 107; in Everett, 2009, p. 341).

\section{Rural business experience economy}

Paraphrasing the seminal article by Pine and Gilmore (1998; in Santini et al., 2011, p. 170) on "experience economy", a firm (or a group of firms, consortia, etc.) working in the rural tourism sector, before charging admission, should design an experience that customers judge to be worth the price. As shown in figure, two dimensions (graphically represented as two axes) are necessary to develop great experiences: customer participation and environmental relationship. The first axis has on one side the concept of "passive participation" where customers do not affect the reality at all, whilst on the other side lies "active participation" in which the tourist has a prominent role in designing the event. The second axis depicts "external relationship" and has at its two extremes "absorption" and "immersion". These two concepts have opposite meanings regarding the level of involvement of the tourist with the context. The spectra of the two dimensions define four categories of experiences: entertainment (in which tourists participate more passively than actively and the connection with the reality in front of them is more of absorption than of immersion), education (when customers are more actively participating but not immersed in the action), escapist (where people are more involved than in educational or entertainment experience) and finally, in the case of less personal participation of tourists, esthetic.

Figure: The four realms of experience

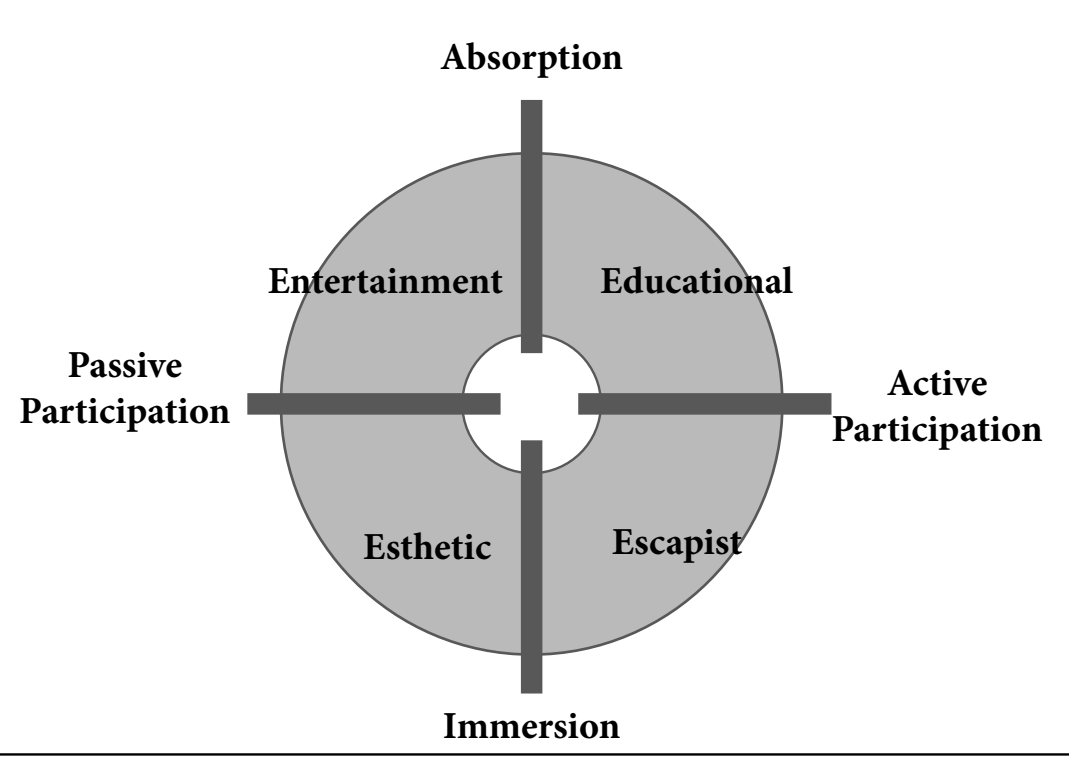

Source: Pine and Gilmore (1998) 
The recipe provided by the authors to design memorable experiences entails five steps:

(a) Theme the experience,

(b) Harmonize impressions with positive cues,

(c) Eliminate negative cues,

(d) Mix in memorabilia,

(e) Engage all five senses.

In summary they can be explained as follows: the theme chosen should conduct the whole experience toward a unified story able to catch the customer attention, involvement and participation through positive and consistent (with the theme) cues that create impressions. Impressions are defined by the authors as the "takeaways of the experience". Thus, each cue or detail needs to be coherent with the general theme given to the experience. In order to do this, it is necessary to avoid every negative cue that might diminish, contradict or distract from the theme. Then, the availability of memorabilia such postcards, $t$ - shirts or other physical reminders of the experience can be important to evoke the impressions. Probably, the most important step to emphasize the magnitude of the experience is the engagement of the five senses. The authors stated that "the more senses an experience engages the more effective and memorable it can be. Not all sensations are good ones and some combinations don't work". Smells, flavors, noises need to be deeply studied to verify any coherence among them and any leaning towards the theme chosen by the local operators. This leads to sensory analysis. Nowadays, many promotional and communicational activities in both the fields of 'food and wine business' and 'tourism sector' are explained using the expression 'sensory analysis'( Santini et al., 2011, p. 171).

\section{Sensory analysis}

What is sensory analysis? According to Drake (2007), sensory science can be traced back to the 1800s, with the development of psychological theories to measures and predict human responses to external stimuli (Lawless \& Heymann, 1999; in Santini et al., 2011, p. 171).

In a recent book edited by Moskowitz, Beckley and Resurrection (2006; in Santini et al., 2011, p. 171), two definitions of sensory evaluation are offered: a) the first is proposed by the institute of Food Technologists and enunciates that "Sensory evaluation is the scientific discipline used to evoke, measures, analyze and interpret reactions to the characteristics of food and materials as they are perceived by the senses of sight, smell, taste, touch and hearing" (retrieved November 10, 2009 from http://www.ift.org/divisions/sensory), b) the second has been elaborated by Herbert Meiselman (1993): "Sensory evaluation is a science of measurement. Like other 
analytical test procedures, sensory evaluation is concerned with precision, accuracy, sensitivity and avoiding false positive results" (Moskowitz et al., 2006; in Santini et al., 2011, p. 171).

From both definitions it is clear that we (Santini et al., 2011, p. 17) are dealing with a science in which statistics cover a prominent role: as a demonstration of this, a new scientific society called the 'sensometric society' has been founded by many researchers belonging to this field of study. It (food tourism) provides a useful avenue in which to undergo a significant shift from tourism as a visual practice towards something which engages all the sense in a kind of sensuous geography (Roadway, 1994), involving the literal and physical internalizing of a culture, as opposed to nonimmersive gaze. These sites provide avenues of total sensual and bodily immersion, where cultural objects are physically internalized and tourists are submerged in waves of smells, sounds, taste and touch (Everett, 2009, p. 342).

It is undeniable that the 'sense of place' has a fundamental relevance for the gastronomic tourist experience. The gastronomic tourists described, here are clearly those identified as 'modern tourists', for whom reality and authenticity 'are thought to be elsewhere; in other historical periods and cultures, in purer, simple life styles' (MacCannell, 1989, p. 3).

However as suggested by Parasecoli (2002; in Scarpato \& Deniele , 2003, p. 301) in the postmodern turn the eatimology of place as a foundation for identities- individual and cultural , local and national' has lost the energy of the past. The eatimologies refer to the analysis of the origin and the development of specific products, their spreading through commerce, cultural expansion, colonization, tourism, and their hybridization (Scarpato \& Deniele, 2003, p. 299). Globalization has increased the speed of kitchen modernization.

Food tourism can be and in many cases already is, driving force for farmers to rethink their production activity taking into account the diversification into new markets and the opportunities to obtain an added value to their products.

Hjalager and Richards (2002, pp. 228-229) suggest that 'a case study can identity relevant issues and the various driving forces that are important for the development of tourism or gastronomy in a particular area' as well as provide a vital basis for a link between theory and practice. Consequently a case study strategy was pursued in order to examine how place and postmodern touristic activity are shaped by food tourism consumption and production in the West of Scotland.

Moreover by participating in food festivals and events, by visiting and buying from specialist food factories by buying from farm shops and farmers "market and by eating at restaurants, pubs and inns which feature local foods /dishes on their menu, the tourist connects closely with the local food culture, starts to understand 
the local food culture, starts to understand the landscape that provided it and directly supports the rural economy" (Hall, 2003).

All these opportunities require human resources and intelligence people informed and able to intelligence, people informed and able to acquire new awareness able to have a new model and a new ethic from which to see food tourism development and the natural resources as complementary for their respective sustainability.

According to Gobe (2001; in Stockebrand et al., 2011, p. 30), emotions have a particular influence on the brand management. The consumer buying decision is not only a result of rational decisions. Furthermore feelings become more important because in many cases consumers are burdened by too much product information. By emotions, Bagozzi et al. (1999; in Stockebrand et al., 2011, p. 30) mean "mental states of readiness that arise from cognitive appraisals of events or thoughts" and in commercial terms" are central to the actions of consumers." Concerning food, Alvensleben (2000; in Stockebrand et al., 2011, p. 30) underlines in his study that especially for regional food, the emotional aspect is very important. In many cases the product quality of regional food cannot be identified by the consumer, so that the buying decision is often a result of emotional attributes of the product or the region in which it is produced. Most studies which focus on communication in tourism underline the importance of emotions- based communication. The power of oral communication has been examined by Salazar (2005) who traced the linguistic skills that tourist guides develop in order to (re)present and actively (re) construct local culture for a diversified global audience. Chronis (2005) demonstrated how symbols inserted into a text can help to negotiate, define, and strengthen social values between service providers and tourists whereas Shin et al. (2008) showed that the use of metaphors significantly influences the purchasing behavior of individuals (Stockebrand et al., 2011, p. 30).

Overall, it appears that the more expressive a communication (i.e., connotative aspects of the message), the more memorable the conveyed information (i.e. the denotative aspects of the message). Against the background, emotional communication seems particularly effective because the connotative aspects such as symbols, metaphors, stories etc. "reduce the complexity of the reality" ( Bosaugit et al.,2009;in Stockebrand et al.,2011, p. 30), by providing a more immediate understanding both of the actors involved in the communication process and of the events portrayed.

Although it is plausible that emotional communication can be particularly effective for representing most components of the tourist product, there is less evidence in the tourist literature whether it is appropriate also for conveying information about the food component whether the latter is set in the foreground of the tourist experience. In fact, whereas tourism is a dynamic, extra - ordinary and un- contextualized (at 
least until it is experienced) concept, food is "concrete, contextualized and lived" (Kniazeva \& Venkatesh, 2007: in Stockebrand et al., 2011,p. 30), This means that it is important to find the right communication for food in tourism since, as underlined by Cohen and Avieli (2004), the culinary aspects of a tourist product can work in its favor or to its detriment: "Since tourists will be generally reluctant to taste or eat (...) foods, whose ingredients are unknown or unfamiliar to them, (the) communication gap between tourist provider and tourists should be reduced in order to avoid any kind of anxiety." They affirm that the communication of food in tourism should "filter out" the elements which are unfamiliar to tourists by means of a "cultural translation". They refer to the process which presence the food component anchored to a familiar context. Thus, the communication of culinary aspects in tourism should create an "environmental bubble" (Cohen \& Avieli, 2004; in Stockebrand, et al., 2011, p. 30) around the tourist. This has a reassuring function which is achieved by using creative techniques such as employing both discursive verbal practices (e.g., labeling dishes with fancy names) or nonverbal ones (e.g., providing pictures of unknown or little known food).

\section{Food Safety}

Food safety is gaining prominence as a consideration by concerned tourists and the wider tourism industry, as awareness of newly emerging food safety issues such as Bovine Spongiform Encephalopathy (BSE- sometimes referred to as 'mad cow' disease) are raised through heightened media attention. Food safety is recognized as one of the three primary concerns raised by participants at the 1998 Think Tank on Safety and Security (International Hotel \& Restaurant Association, 1998; in Pendergast, 2006, p.143). They have focused on the particular characteristics with the nature of food-borne illness, the extent that it strikes the tourism market, the potential for genuine partnerships to make a difference and how being an active agent, including knowing which foodstuffs to avoid, might be a useful strategy for minimizing the potential time spent engaged with a pedestal, rather than in more appealing tourist activities.

A sickness caused by eating contaminated food is often called 'food poisoning', or more correctly, 'food-borne illness'. In almost all cases, this illness can be easily prevented with the use of careful food-handling and storage techniques, personal hygiene practices and cleaning processes, particularly in mass catering settings such as restaurants, hotels and takeaways, thereby reducing the opportunity for foodborne illness occur (Pendergast, 2006, p.146).

The Federation of Tour Operators (FTO) has developed a preferred Code of Practice (FTO, 2003) which provides advice regarding a range of elements at tourist destination including those related to: fire safety, pool safety, beach safety, children's 
clubs; and importantly, food safety. The document has been "issued to 18000 accommodation providers in destination, and is the criteria that our members and experts use to measure acquiescence" (FTO, 2005; in Pendergast, 2006, p. 151).

\section{Lessons to Learn}

Slow Food association in Italy has recently launched a project in 1999 that uses two tools to protect and promote typical foods for promoting food tourism in Italy. Those two tools are: Presidia Projects and Ark of Taste. The presidia began in Italy in 1999 as the supporting arm of Ark of Taste. The Ark had catalogued hundreds of products at risk of disappearing, but with the presidia, Slow Food decided to make a concrete contribution to the world of production. Presidia is a local projects that focus on a group of producers of a single product, developing production and marketing techniques to allow their work to be economically viable. The presidia program is the tool that Slow Food uses to assist producers directly in the commercialization, protection and promotion of their products.

The general objectives of the presidia cover the following four areas: economic objectives (increasing producer incomes, developing local driven activities, increasing employment); environmental objectives (defending biodiversity, improving the sustainability of products); social objectives (improve the social position of producers, strengthen their organizational capacity); and cultural objectives (strengthening producers' cultural identity and promoting production areas) (Buiatti, 2011, p. 96).

Main goals of Slow Food Association (Buiatti, 2011, p. 97)

- To protect the heritage of food, local traditional and different cultures

- To defend food biodiversity

- To safeguards the environment and the land

- To promote taste education in order to help to make daily choices about food with awareness and responsibilities

- To endorse sustainable agriculture

- To protect small producers and their communities

- To promote gastronomic traditions of the world.( Source: Retrieved January 7, 2010, from www.slow food.com; in Buiatti, 2011, p. 97 )

One of the key components of the relationship between food and tourism and regional development is that of the promotion of local foods (Hall, 2002). As well as direct purchase by consumers, the use of local food production, while branding menus in terms of their local food content may also be significant in marketing the menu and the restaurant as well as potentially leading to ongoing purchase of regional food - stuffs by consumers. Additionally, the use of local foods may add to 
the perceived authenticity of the restaurant experience as well as the wider experience of the destination (Symons, 1999).

Food tourism is strictly related to the development of a sustainable tourism which has its main objective to minimize environmental and cultural change, maximize tourist satisfaction, and optimize long-term economic growth for the region. It is a way of obtaining a balance between the growth potential of tourism and the conservation need of the environment (Buiatti, , p. 100).

In the postmodern era, festivals and, events have provided communities with an effective means of affirming their cultural and regional values and identities. Moreover, by participating in food festivals and events, by visiting and buying from specialist food factories, by buying from farm shops and farmers' market and by eating at restaurants, pubs and inns which feature local foods/dishes on their menu, the tourist connects closely with the local food culture, starts to understand the landscape that provided it and directly supports local economy (Hall, 2003, p. 10).

\section{Food Tourism and Destination Brand}

Food can also be used in branding a destination (Hashimoto and Telfer, 2006; in Lin et al.,2011, p.32).In forming brand associations with respect to a specific destination, it is widely suggested that brand name, logo, symbol, slogan and packaging are key elements, and that each of these elements should reflect the characteristics of the destination (Cai, 2002; Tasci \& Kozak, 2006; in Lin et al., 2011, p. 32). In light this perspective, food can be considered an essential element in building a destination brand (Hashimoto \&Telfer,2006; in Lin et al., 2001, p. 32),because food is often intertwined with the social, cultural and natural characteristics of a specific region, and therefore carries a large number of symbolic meanings (Lockie, 2001; in Lin et al., 2011, p. 32).Food has a strong connection to a place. French wines (Henchion and Mclntrye, 2000; in Lin et al., 2011, p. 32), Italian pasta (Alexander, 2000) and Cajun cuisine (Ten Eyck, 2001) are good examples. In light of this fact, the distinctiveness of food in relation to a place plays a significant role in a destination identity (Everett and Aitchison, 2008; in Lin et al., 2011, p. 32)

Similarly, from a marketing perspective, although brand identity and brand image are related, they are different concepts. The key difference between these two concepts is that identity originates from the firm, whereas image is an individual's perception of a particular brand (Nandan, 2005; in Lin et al., 2011, p. 34). A brand has to prioritize its focus on the brand identity that enables its target customer to evaluate a particular brand accurately and properly (Ghodeswar, 2008; in Lin et al., 2011, p. 34). Aaker (1996; Lin et al., 2011, p.34) delineates that brand identity includes a core and extended identity. The core identity, the central of the brand, makes the brand unique and valuable. Specifically, the elements of the core identity should reflect the 
meaning and essence of the brand. To become a strong and successful brand, not only is a clear and competitive core identity needed, but well-organized and cohesive elements of extended identity are also essential (Aaker, 1996). In this sense, brand identity needs to fairly reflect the firm's business strategies in terms of its promises to customers (Aaker \& Joachimsthaler, 2000; in Lin et al., 2011, p. 34). That is, brand message has to be conveyed clearly (Nandan, 2005). As a result, researchers suggest that brand identity is a theoretical concept that would be best understood from the supply-side perspective (Nandan, 2005). In line with this perspective, Cai (2002; in Lin et al., 2011, p. 34) argues that image building comes one step closer to branding, but it lacks a critical link - a brand identity.

After analyzing food-related information present in tourism brochures and destination website, a frame work for the identity of food in relation to a destination is proposed. This framework consists of 7 dimensions and 14 categories with number of items. Seven dimensions, along with the specific categories, are described in the table given below.

Table: A Framework of an identity of food in relation to a destination

\begin{tabular}{|l|l|l|}
\hline Dimension & Category & Example item \\
\hline Class of food & A type of food & $\begin{array}{l}\text { Raw, cooked, packaged, drink } \\
\text { and snack }\end{array}$ \\
\hline Role of food & A style of food & $\begin{array}{l}\text { Traditional, regional, } \\
\text { international and fusion }\end{array}$ \\
\hline Aharacter of food & Astablishment & $\begin{array}{l}\text { Restaurant, café, shop, market } \\
\text { and farm }\end{array}$ \\
\hline A food-related activity & $\begin{array}{l}\text { Festival, tour, holiday } \\
\text { celebration and exhibition }\end{array}$ \\
\hline Value of food & $\begin{array}{l}\text { As an indicator of a } \\
\text { society }\end{array}$ & $\begin{array}{l}\text { Custom, history, religion and } \\
\text { pop culture }\end{array}$ \\
& $\begin{array}{l}\text { As a reflection of a } \\
\text { status }\end{array}$ & $\begin{array}{l}\text { Mountain, land, sea, river and } \\
\text { weather }\end{array}$ \\
\hline Dining experience & $\begin{array}{l}\text { Authentic, ethnic, trendy, } \\
\text { exotic and religious }\end{array}$ \\
\hline & $\begin{array}{l}\text { Social and cultural } \\
\text { experiences }\end{array}$ & $\begin{array}{l}\text { With families, friends and a } \\
\text { specific group people }\end{array}$ \\
\hline
\end{tabular}




\begin{tabular}{|l|l|l|}
\hline & Sensory quality & $\begin{array}{l}\text { Taste, appearance, smell, } \\
\text { freshness and texture }\end{array}$ \\
\hline & Promised quality & $\begin{array}{l}\text { Food safety, health, claim and } \\
\text { labeling }\end{array}$ \\
\hline $\begin{array}{l}\text { Feature of food and } \\
\text { food-related subjects }\end{array}$ & $\begin{array}{l}\text { A feature of food or } \\
\text { food-related subjects }\end{array}$ & $\begin{array}{l}\text { Origin, ingredient, recipe, } \\
\text { and preparing and farming } \\
\text { methods }\end{array}$ \\
\hline $\begin{array}{l}\text { Attribute of } \\
\text { foodservice }\end{array}$ & $\begin{array}{l}\text { An attribute of } \\
\text { foodservice }\end{array}$ & $\begin{array}{l}\text { Service type, amenity, décor, } \\
\text { dining setting and special offer }\end{array}$ \\
\hline $\begin{array}{l}\text { Availability of food } \\
\text { and food-related } \\
\text { subjects }\end{array}$ & $\begin{array}{l}\text { An availability of } \\
\text { food and food-related } \\
\text { subjects }\end{array}$ & $\begin{array}{l}\text { Days open, price, phone, } \\
\text { address, transportation and } \\
\text { map }\end{array}$ \\
\hline
\end{tabular}

Source: Lin et al., 2011, p.38

National and cultural identity is one of the most obvious ways of distinguishing food systems as Other. It is also the frequent category in which culinary tourism is enacted, giving us international dinners, cookbooks and restaurants specializing in the cuisine of particular cultures, and classes televised cooking shows demonstrating cooking techniques from a variety of cultures. This category is based partly on spatial distance and physical boundaries between groups of people. A food system physically removed from the familiar can automatically, though not necessarily, represent the unknown, and therefore, be potentially strange. This spatial distance also refers to the juxtaposition of foodways of varying cultures that have historically had physical distance, usually with the locating of one identity within the context of another, turning the former identity ethnic (FN6). Ethnicity, like Otherness, is a dynamic cultural construct, and is more usefully thought of as a process of contextualization rather than an actual objective state. Ethnic identity is based on perceptions of shared heritage and of living within a dominant host culture (Oring, 1986, p. 24; in Long, 1998, p. 183).

\section{Conclusion}

Food is the manifestation of exchange crossing the boundary (symbolically the mouth) between inner self and the outer world. Food not only provides energy but also it gives the identify of people and their places. Food has been associated with culture and heritage. People wherever they have settled they eat different types of food which are produced according to the nature of its ecology and environment. Food is cultural artifact that could be divided into two: the sacred and secular food. Food habit, dietary pattern, way of eating and sitting seem to be important for understanding human society and their culture. 
People in this modern world have developed their mode of travelling for having different taste of food. Thus, food tourism as a different form of tourism came into existence in the arena of tourism. In tourism, food seems to be one of the most important economic sources for the local communities of destinations. Food tourism provides a conceptual vehicle for pursuing a more culturally aware tourism agenda. (Everett, 2009) Many food tourists are seeking for authenticity because many of them are frustrated with repeated food stored in refrigerator.

In course of studying food tourism, the scholars of this subject also focused on culinary tourism, gastronomic tourism interchangeably. Food tourism has also been linked with slow food, slow tourism, slow tourist and slow city. Though this was a movement, people are highly influenced from this movement and made efforts to make success this. Today many tourist destinations are with this project which have focused on sustainability trinity (social, economic and environment). Many destinations have used food as source of attraction in strengthening their tourism marketing. Attention must be given on food safety and security. Food is considered as one of the "holy trinity" (Brotherton, 1999; Bell, 2009; Kunwar, 2017). Bell (2009) in this regard has used the term "holy trinity", first used by Brotherton (1999) which refers to foodscapes, drinkscapes and restscapes in business and managerial terms.

Food tourism research is very popular in Europe but not in Nepal, one of the most richest destinations, where people consume chaurasi benjan (84 different dishes) consumed by Hindus and many more different types of food and drinks by different ethnic groups. The main reason of not studying on food tourism in Nepal is because there has not been developed food as a tourism product in scientific way. Therefore, this is high time that Nepal tourism authorities should learn, understand and come up with its indigenous strategies to identify, protect and promote the aspects of food tourism in Nepal.

\section{Acknowledgements}

First and foremost, I would like to express my sincere thanks to Mr. Basanta P. Joshi of AITM WhiteHouse College, Rajan Rai and Anub Bhandari of CPDS, Nimesh Ulak of IST College, Manish Ranabhat and Sunil Lama of Gateway College, Srija Humagain and Smriti Rai of Gate College who helped me a lot for preparing this article.

\section{References}

Association of Nepalese in America (1996).The Nepal Cook Books, Delhi: New Age Books.

Backman, K.F. \& Morais, D.B.(2001). "Methodological approaches used in the literature" in Weaver, D.B. (ed.) The Encyclopedia of Ecotourism(pp.597-609),CABI Publishing. 
Belisle, F.J.(1983). Tourism and food production in the Caribbean.Annals of Tourism Research, 10(4), 497-513.

Bell, D. (2009). Tourism and hospitality. In Jamal, T.\& Robinson, M. (eds.). The Sage Handbook of Tourism Studies (pp.19-34), London: Sage.

Bell, D. \&Valentine, G.(1997).Consuming geographies. We are where we eat, London: Routledge.

Boyne, S.\&Hall, D. (2003). Managing food and tourism developments: Issues for planning and opportunities to add value. In Hall, C.M., Sharples, L., Mitchell, R., Macionis, N. \& Cambourne, B. (eds.) Food Tourism Around the World: Development, management and markets (pp.285-295), Oxford: Butterworth/ Heinemann.

Brotherton, B. (1999). Towards a definitive view of the nature of hospitality and hospitality management. International Journal of Contemporary Hospitality Management, 11 (4), 165-173.

Buiatti, S. (2011). Food and tourism: The role of the "Slow Food" Association. In Sidali, K.L,Spiller, A. \& Schulze, B. (eds.) Food, Agri-Culture and Tourism,Linking Local Gastronomy and Rural Tourism : Interdisciplinary Perspectives (pp.92-101), Springer-Verlag Berlin, Heidelberg.

Camp, C. (2006), Review. Culinary Tourism, Western Folklore, 65(3), 377-379.

Canavari, M., Huffaker, C., Mari, R., Reggazi, D., \&Spadoni, R.(2011). "Educational firms in the Emilia- Romagna region: the role in food habit education", in Sidali, K. L., Spiller, A. \& Schulze, B. ( eds.) Food, Agri-Culture and Tourism Linking Local Gastronomy and Rural Tourism: Interdisciplinary Perspectives (pp.73-91), Springer-Verlag Berlin, Heidelberg.

Chai, S.K. (2005). Review. Culinary Tourism, Gastronomica, 5(4), 121-122.

Cook, I. \& Crang, P.(1996). The world on a plate: Culinary cultures, displacement and geographical knowledge, Journal of Material Culture, 1 (2), 131-153.

Derek, H. \&Boyne, S.(2003). Managing food and tourism developments: issues for planning and opportunities to add value. In Hall, C.M., Sharples, L., Mitchell, R., Macionis, N. \& Cambourne, B. Food Tourism Around the World:Development, management and markets (pp. 285-295),Oxford: Butterworth/Heinemann.

Doshi, S.L. (1995). Anthropology of Food \& Nutrition, Jaipur: Rawat Publications.

Eastham, J.F.(2003). Valorizing through tourism in rural areas: Moving forwards regional partnerships. In Hall, C.M., Sharples, L., Mitchell, R., Macionis, N. \&Cambourne, B. (eds.) Food Tourism Around the World: Development, management and markets (pp. 229-248), Oxford: Butterworth/Heinemann. 
Everett, S.(2009). Beyond the visual gaze? The pursuit of an embodied experience through food tourism. Tourist Studies, 8(3), 337-358.

Hall, C.M \&Sharples, L.(2003). The consumption of experiences or the experience of consumption? An introduction to the tourism of taste. In Hall, C.M., Sharples, L., Mitchell, R., Macionis, N. \& Cambourne, B.(eds.) Food Tourism Around the World:Dvelopment, management and markets, (pp.1-24), Oxford: Butterworth/ Heinemann.

Hall, C.M., Mitchell, R. \& Sharples, L.(2003). Consuming places: the role of food, wine and tourism in regional development. In Hall, C.M., Sharples, L. Mitchell, R. Macionis, N. \& Cambourne, B.(eds.), Food Tourism around the world:Development, management and markets, (pp. 25-59).Oxford: Butterworth/Heinemann.

Hannerz, U.(1990). Cosmopolitans and locals in a world culture, Theory Culture and Society, 237-251.

Hasimoto, A. \& Telfer, D.J.(1999). Marketing icewine to Japanese tourists in Niagara: The case of Inniskillin winery, International Journal of Wine Marketing, 11(2), 29-41.

Heitmann, S., Robinson, P. \& Povey, G. (2011). Slow Food, Slow Cities and Slow Tourism. In Robinson, P., Heitmann, S. \& Dieke, P. (eds.) Research Themes for Tourism (pp.233-248), Wallingford: Cabi.

Holden, A.(2007). Environment and Tourism, London: Routledge.

Hughes, G. (1995). Authenticity in tourism, Annals of Tourism Research, 22 (4), 781803.

Majupuria, I.(2008). Joys of Nepalese Cooking, Lashkar (Gwalior): S.Devi.

Kansakar, N.H.(1994). Nepali Kitchens, Kathmandu: Dorothy Miller.

Khanal, D.(2016). From Nepal to the World: 100 Ethnic Dishes of Nepal. HM's Food \& Wine, Kathmandu.

Kunwar, R.R.(1999).Fire of Himal:An Anthropological Study of the Sherpas of Nepal Himalayan Region, Jayapur: Nirala.

Kunwar, R.R. (2011). Special Interest Tourism: A Study of Growing Significance of Food Tourism. The Gaze Journal of Tourism and Hospitality, 3(1), 77-97.

Kunwar, R.R. (2017). What is hospitality? The Gaze Journal of Tourism and Hospitality, 8(1), 55-115.

Lashley, C., Lynch, P.A. \&Morrison, A. (eds.) (2007).Hospitality: A Social Lens, Oxford: Elsevier.

Lin, Y-C, Pearson, T. E \$ CAI, (2011). Food as a form of destination identity. A tourism destination brand perspective. Tourism and Hospitality Research, 11(1), 30-48. 
Lockwood, Y.R. (2008). Review. Culinary Tourism, Journal of American Folklore, 121(481), 362-363.

Long, L. M. (1998). Culinary tourism: A folkloristic perspective on eating and otherness. Southern Folkore, 55 (3): 181- 204.

Lowdin, P. (1998).Food, Ritual and Society: A Study of Social Structure and Food Symbolism among the Newars, Kathmandu: Mandala Book Point.

MacLaurin, T.L. (2001). Food safety in travel and tourism.Journal of Travel Research, 39 (3), 332-333.

Mitchell, R.,Hall, C.M. \&Johnson, G.(2001).Food and drink in the New Zealand tourism experience. In Butcher, J. (ed.) Innovations in Cultural Tourism (pp. 7591). ATLAS.

Mitchell, R.D., Hall, C.M. \&McIntosh, A.J.(2000). Wine tourism and consumer behavior. In Hall, C.M., Sharples, E.B. Combourne, N. Macionis (eds.) Wine Tourism Around the World: Development, Management and Markets(pp. 115135), Oxford: Butterworth - Heinemann.

McCannell, D.(1976).The Tourist: A New Theory of Leisure Class, London: Macmillan.

O'Gorman, K.D.(2010). The Origins of Hospitality and Tourism, Oxford: Goodfellow Publishers.

Pathak, J.(2011).Taste of Nepal, New Delhi: Adarsha Books.

Pendergast, D. (2006). Tourist Gut Reaction: Food Safety and Hygiene Issues. In Pendergast, D \& Leggat, P. (eds.) Tourism in Turbulent Times: Towards Safe Experiences for Visitors (pp.143-154), Amsterdam: Elsevier.

Pine II, B.J. \& Gilmore, J.H. (1998). Welcome to the Experience Economy. Harvard Business Review.

Porter, M. (1990).The Competitive Advantage of Nations, Macmillan.

Povey, G. (2012). Gastronomy and food tourism. In Robinson, P. (ed.) Tourism The Key Concepts(pp. 82-85), London: Routledge.

Ratna Pustak Bhandar (2007).Cooking in Nepal, Kathmandu: Ratna Pustak Bhandar.

Reisinger, Y. (2009). International Tourism Cultures and Behavour, Elsevier.

Relph E., (1996). Place. In Douglas, I., Huggett, R. \&Robinson, M. (eds.), Companion Encyclopedia ofGeography: The Environment and Humankind, Routledge.

Reynolds, P. (1993). Food and tourism: towards an understanding of sustainable culture,Journal of Sustainable Tourism, 1 (1), 48-54. 
Rusher, K.(2003). The Bulf oyster festival and regional economic development festivals as culture commodified. In Hall, C.M., Sharples, L., Mitchell, R., Macionis, N. \&Cambourne, B. (eds.) Food TourismAround the World: Development, management and markets (pp. 192-205). Oxford: Butterworth - Heinemann.

Rimmington, M. \& Yuksel, A.(1998). Tourist satisfaction and food service experience: Result and implications of an empirical investigation, Anatolia. 9 (1), 37-57.

Rombach, M.S Bitsch,V.(2015) Food Movements in Germany: Slow Food, Food Sharing and Dumptster Diving. International Food and Agrobusiness Management Review, 18(3), 1-24.

Scarpato, R. \& Roberto, D. (2003). New global cuisine: tourism, authenticity and sense of place in postmodern gastronomy. In Hall, C.M., Sharples, L., Mitchell, R., Macionis, N. \& Cambourne, B. (eds.) Food Tourism Around the World: Development, management and markets (pp. 296-313), Oxford: Butterworth Heinemann.

Sharples, L.(2003). Food tourism in the peak district national park, England. In Hall, C.M., Sharples, L., Mitchell, R., Macionis, N. \& Cambourne, B. (eds.), 2003, Food Tourism Around the World: Development, management and markets (pp. 206227). Oxford: Butterworth-Heinemann.

Sheringham, C. \& Daruwalla, P. (2007). Transgressing Hospitality: Polarities and Disordered Relationships? In Lashley, C., Lynch, P. \& Morrison, A. (eds.) Hospitality A Social Lens (pp. 33-46), Amsterdam: Elsevier.

Simpson, T.(1999).A Distant Feast: The Origins of New Zealand's Cuisine. Random House, New Zealand.

Smith, M., Macleod, N. \& Hart Robertson, M. (eds.) (2010). Key Concepts in Tourism (pp.75-79), London: Sage.

Santini, C., Cavicchi, A. \&Canavari, M.(2011). The Risk ${ }^{\mathrm{TM}}$ strategic game of rural tourism: How sensory analysis can help in achieving a sustainable competitive advantage. In Sidali, K.L., Spiller, A. \& Schulze, B. (eds.) Food, Agri-Culture and Tourism Linking Local Gastronomy and Rural Tourism: Interdisciplinary Perspectives (pp.161-179) Springer-Verlag Berlin, Heidelberg.

Santich, B. (2007). Hospitality and gastronomy: Natural Allies. In Lashley, C., Lynch, P. \& Morrison, A. (eds.) Hospitality A Social Lens (pp.47-60), Amsterdam: Elsevier.

Smith, A. \& Hall, C.M.(2003). Restaurants and local food in New Zealand. In Hall, C.M., Sharples, L., Mitchell, R., Macionis, N. \&Cambourne, B. (eds.)Food Tourism: around the world: development, management and markets (pp. 249-267). Oxford: Butterworth/Heinemann. 
Sims, R. (2009). Food, place and authenticity: local and the sustainable tourism experience. Journal of Sustainable Tourism,17(3):321-336

Smith, M., Macleod, N. \& Hart Robertson, M. (2010). Key Concepts in Tourist Studies, London: Sage.

Stockebrand, N., Sidali, K.L. \&Spiller, A.(2011). Pers[ectives of emotional food communication for farm operators. In Sidali, K.L., Spiller, A. \& Schulze, B.(eds.) Food, Agri-Culture and Tourism linking Local Gastronomy and Rural Tourism: Interdisciplinary Perspectives (pp.25-40), Springer- Verlag Berlin, Heidelberg.

Strauss, C. L. (1978). The Origin of Table Manners, Harper Collins.

Stierand, M.B. (2013). Gastronomy and Haute Cuisine. in Wood, R.C. (ed.). Key Concepts in Hospitality Management (pp.50-54), London: Sage.

Swarbrooke, J. \& Horner, S.(1999).Consumer Behavior in Tourism, Oxford: Butterworth-Heinemann.

Telfer, D. J. \&Wall, G.(1996). Linkages between tourism and food production, Annals of tourism Research, 23(3), 635-653.

Vaidya, H.(1999). Nepalese Cookery, Kathmandu: Sahayogi Press.

Van, Keken, G. \& Go, F. Close encounters: The role of culinary tourism and festivals in positioning a region. In Burns, P.M. \& Novelli, M. (eds.) Tourism and social identities: Global Frameworks and local realities, Amsterdam: Elsevier.

Visentin, C. (2011). Food, Agri-Culture and Tourism. In Sidali, K.L., Spiller, A. \& Schulze, B. (eds.) Food, Agri-Culture and Tourism Linking Local Gastronomy and Rural Tourism: Interdisciplinary Perspectives (xiii-xv), Springer- Verlag Berlin, Heidelberg.

Waits, M. J. (2000). The added value of industry cluster approach to economic analysis strategy development, and service delivery, Economic Development Quarterly, 14, 35-50.

Zelinsky, W. (1997). The roving palate: North America's ethnic restaurant cuisines. Geoforum, 16 (1), 51-72. 